\title{
Leptin's effect on puberty in mice is relayed by the ventral premammillary nucleus and does not require signaling in Kiss1 neurons
}

\author{
Jose Donato Jr., ${ }^{1,2}$ Roberta M. Cravo, ${ }^{1}$ Renata Frazão, ${ }^{1}$ Laurent Gautron, ${ }^{1}$ \\ Michael M. Scott, ${ }^{1}$ Jennifer Lachey, ${ }^{3}$ Inar A. Castro, ${ }^{4}$ Lisandra O. Margatho, ${ }^{1}$ Syann Lee, ${ }^{1}$ \\ Charlotte Lee,, James A. Richardson, ${ }^{5}$ Jeffrey Friedman, ${ }^{6}$ Streamson Chua Jr., ${ }^{7}$ \\ Roberto Coppari, ${ }^{1}$ Jeffrey M. Zigman, ${ }^{1,8}$ Joel K. Elmquist, ${ }^{1,8,9}$ and Carol F. Elias,
}

\begin{abstract}
${ }^{1}$ Department of Internal Medicine, Division of Hypothalamic Research, University of Texas Southwestern Medical Center, Dallas, Texas, USA. 2Department of Anatomy, Institute of Biomedical Sciences, University of São Paulo, São Paulo, Brazil. ${ }^{3}$ Acceleron Pharma, Boston, Massachusetts, USA. ${ }^{4}$ Department of Food and Experimental Nutrition, Faculty of Pharmaceutical Sciences, University of São Paulo, São Paulo, Brazil. ${ }^{5}$ Department of Pathology, University of Texas Southwestern Medical Center, Dallas, Texas, USA.

${ }^{6}$ Laboratory of Molecular Genetics and Howard Hughes Medical Institute, The Rockefeller University, New York, New York, USA. 7 Departments of Medicine and Neuroscience, Albert Einstein College of Medicine, New York, New York, USA.

${ }^{8}$ Department of Psychiatry and ${ }^{9}$ Department of Pharmacology, University of Texas Southwestern Medical Center, Dallas, Texas, USA.
\end{abstract}

\begin{abstract}
Studies in humans and rodents indicate that a minimum amount of stored energy is required for normal pubertal development. The adipocyte-derived hormone leptin is a key metabolic signal to the neuroendocrine reproductive axis. Humans and mice lacking leptin or the leptin receptor (LepR) (ob/ob and $d b / d b$ mice, respectively) are infertile and fail to enter puberty. Leptin administration to leptin-deficient subjects and $o b / o b$ mice induces puberty and restores fertility, but the exact site or sites of leptin action are unclear. Here, we found that genetic deletion of LepR selectively from hypothalamic Kiss1 neurons in mice had no effect on puberty or fertility, indicating that direct leptin signaling in Kiss1 neurons is not required for these processes. However, bilateral lesions of the ventral premammillary nucleus (PMV) of $o b / o b$ mice blunted the ability of exogenous leptin to induce sexual maturation. Moreover, unilateral reexpression of endogenous LepR in PMV neurons was sufficient to induce puberty and improve fertility in female LepR-null mice. This LepR reexpression also normalized the increased hypothalamic GnRH content characteristic of leptin-signaling deficiency. These data suggest that the PMV is a key site for leptin's permissive action at the onset of puberty and support the hypothesis that the multiple actions of leptin to control metabolism and reproduction are anatomically dissociated.
\end{abstract}

\section{Introduction}

The existence of a fundamental link between nutrition and reproduction is well established. Early studies in humans and rodents suggested that a minimum amount of stored energy is required for normal pubertal development and to maintain the tone of the reproductive system $(1,2)$. This concept is based on the idea that when survival is threatened by scarcity of food or increased energy demands, males and females of most species divert energy away from reproduction. This includes sexual maturation, the production of reproductive hormones and gametes, and the maintenance of pregnancy and lactation. On the other hand, excess energy may have a negative impact on the reproductive physiology. For example, elevated adiposity in women aggravates polycystic ovarian syndrome and ovulatory dysfunctions and may induce hypothalamic hypogonadism $(3,4)$. Moreover, the increasing rates of childhood obesity have been associated with the advance in the timing of pubertal maturation and its deleterious consequences (5-8). Earlier menarche in girls is correlated with increased risk of adult obesity, type 2 diabetes, and breast cancer $(9,10)$. Thus, changing levels of key metabolic cues is an essential signal for the onset of puberty. But the assessment of the mechanisms underlying puberty initiation has been obstructed by the lack of information on the brain sites in which this event is integrated.

Authorship note: Jose Donato Jr. and Roberta M. Cravo are co-first authors. Conflict of interest: The authors have declared that no conflict of interest exists. Citation for this article: JClin Invest. 2011;121(1):355-368. doi:10.1172/JCI45106.
It is now well known that the adipocyte-derived hormone leptin signals the amount of energy stored to the neuroendocrine reproductive axis. Mice lacking leptin $(o b / o b)$ or the leptin receptor (LepR) $(d b / d b)$ develop hyperphagic obesity as well as diabetes and are infertile (11-13). These mice exhibit low luteinizing hormone (LH) levels and incomplete development of reproductive organs and do not undergo puberty. Leptin administration to $o b / o b$ mice, but not weight loss alone, induces pubertal development and maturation of reproductive organs, increases LH secretion, and restores fertility (14-16). The leptin-deficient reproductive phenotype is recapitulated in humans with monogenic forms of leptin deficiency (17). In leptin-deficient subjects, leptin treatment induces an increase in the levels of gonadotropins and sex steroids as well as enlargement of the gonads and normal pubertal development $(18,19)$.

LepR is expressed in many organs and tissues $(13,20)$, but studies using genetically engineered mouse models have determined that the brain plays a major role (21-23). Compelling evidence supports the concept that leptin acts indirectly on gonadotropinreleasing hormone-secreting ( $\mathrm{GnRH}$-secreting) cells via actions on leptin-responsive afferent neurons $(24,25)$. Thus, efforts have been made to identify the key site(s) or neuronal populations that mediate leptin's effects on GnRH secretion.

Significant attention has been given to neurons from the arcuate nucleus (Arc), where LepR is colocalized with POMC, AgRP/NPY, and Kiss1 neurons (26-28). A number of studies have indicated that melanocortin neurons are not the key link between leptin and the 

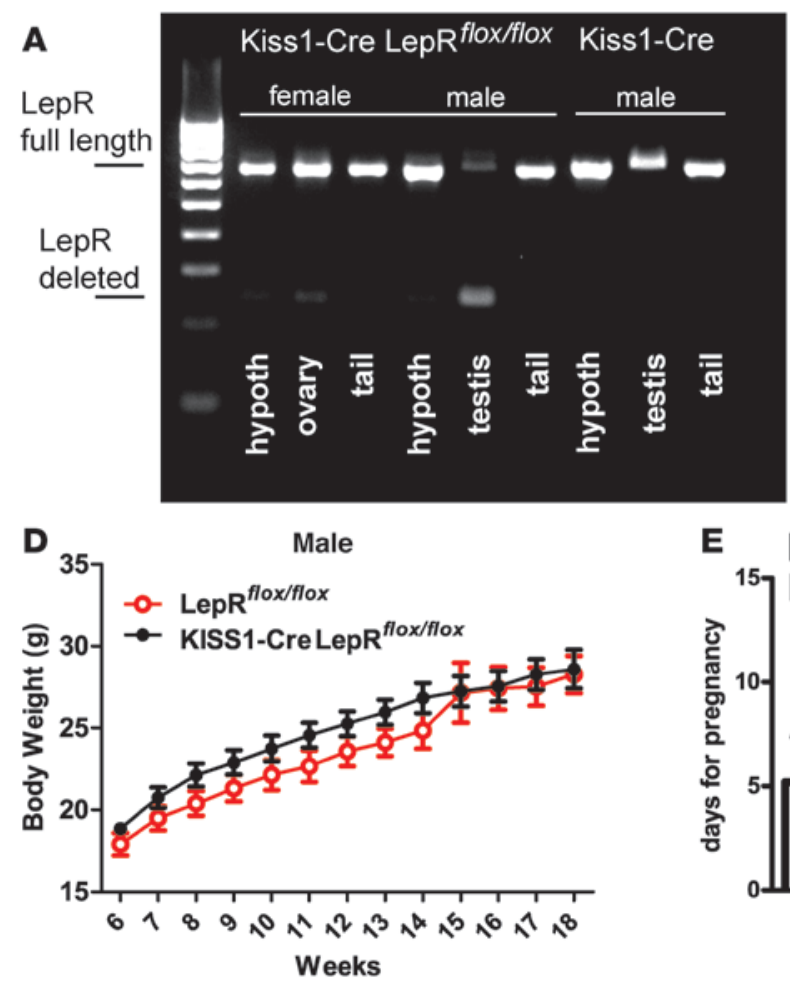

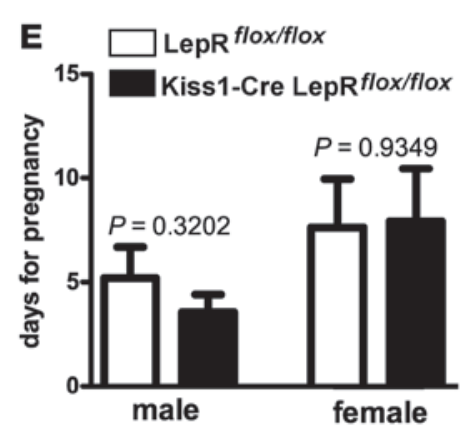

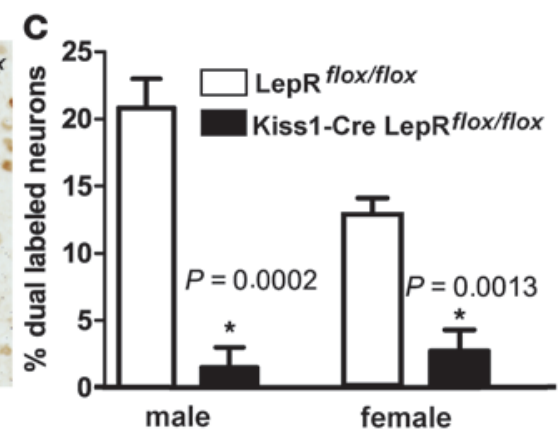

$\mathbf{F}$

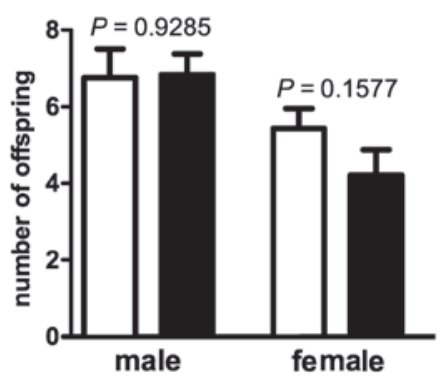

Figure 1

Leptin signaling in Kiss1 neurons is not required for puberty and fertility. (A) Product of PCR showing sites of DNA recombination in male and female mice with deletion of LepR from Kiss1 cells compared with a control mouse. Note the deletion of LepR from Kiss1 cells in the hypothalamus and gonads; (B) coexpression of leptin-induced pSTAT3 in Kiss1 neurons of the Arc; (C) quantification of Kiss1 neurons expressing leptin-induced pSTAT3 in the Arc of Kiss1-Cre LepR flox/flox mice and of LepR floxfflox littermates. (D-F) Graphs showing no changes in body-weight (D), in time for pregnancy (E), and in fecundity (number of offspring, F) comparing Kiss1-Cre LepR ${ }^{\text {flox/flox }}$ and LepR ${ }^{\text {flox/flox }}$ littermates. *Statistically different from LepR flox/flox littermates. Data are expressed as mean \pm SEM. Scale bar: $200 \mu \mathrm{m}$.

reproductive axis (29-32). But, alternatively, a series of findings have suggested that Kiss1 neurons are potential candidates to mediate leptin's effect on reproduction. Leptin-deficient $o b / o b$ male mice show decreased expression of Kiss 1 in the Arc, which is increased by leptin treatment (28). Hypothalamic Kiss 1 mRNA levels are decreased in male rats made diabetic by administration of streptozotocin (33). Intracerebroventricular administration of leptin normalizes Kiss 1 gene expression and the levels of LH and androgens. However, the requirement of leptin signaling on Kiss 1 neurons for normal pubertal development has not been directly tested.

We recently showed that adult female rats with bilateral lesions of the ventral premammillary nucleus (PMV) are unresponsive to leptin's effect to induce LH secretion during fasting (34). However, this experimental model was not suitable to assess whether leptin signaling in PMV neurons is required and/or sufficient for leptin's effects on pubertal development. In the current study, we have used multiple genetic mouse models to determine the specific brain site or sites underlying leptin's permissive action in the onset of puberty.

\section{Results}

Deletion of LepR selectively from Kiss1 neurons. To determine whether LepR signaling in Kiss 1 neurons is required for pubertal development, we used the Cre/loxP system to delete LepR selectively from Kiss 1 neurons. Mice lacking LepR only in Kiss1 neurons were obtained by crossing Kiss1-Cre mice (line J2-4, pure C57BL/6 background) with mice homozygous for a loxP-modified Lepr allele (LepR ${ }^{\text {lox } / l o x}$, mixed $129-\mathrm{C} 57 \mathrm{BL} / 6$ background). These mouse models have been previously verified and validated $(31,35,36)$. Two cohorts of Kiss $1-C r e$ LepR $\mathrm{R}^{\text {flox/flox }}$ mice $(n=13$ males and $n=8$ females) and LepR ${ }^{\text {flox } / f l o x}$ littermates $(n=13$ males and $n=11$ females) were evaluated. In parallel, Kiss1-Cre mice (lacking the loxP-modified Lepr allele) and WT littermates (lacking both the Kiss1-Cre and the loxP-modified Lepr allele) ( $n=4$ per sex and per genotype) were also monitored as additional controls. Groups were defined by tail genotyping, and deletion of LepR from Kiss 1 neurons was assessed at the end of the experiment. The selective deletion of LepRs from Kiss1 neurons in Kiss1-Cre LepR ${ }^{\text {flox/flox }}$ mice was validated by identification of DNA recombination using a PCR strategy in which the presence of full-length and Cre-mediated deletion of the Lepr gene was distinguished ( $n=4$ per sex and per genotype). We found that the Lepr gene sequence flanked by loxP sites was successfully deleted from the genome only in tissues that express Kiss1, including the hypothalamus and gonads (Figure 1A). To further validate the loss of functional LepRs in Kiss 1 neurons, mice were fasted for 24 hours and treated with i.p. leptin $(5 \mu \mathrm{g} / \mathrm{g})$ 45 minutes before perfusion ( $n=4$ per sex and per genotype). Brain sections were processed for immunohistochemistry to detect leptin-induced phosphorylation of the STAT3 (pSTAT3) as a marker for leptin signaling $(37,38)$. Mice used in this histological 


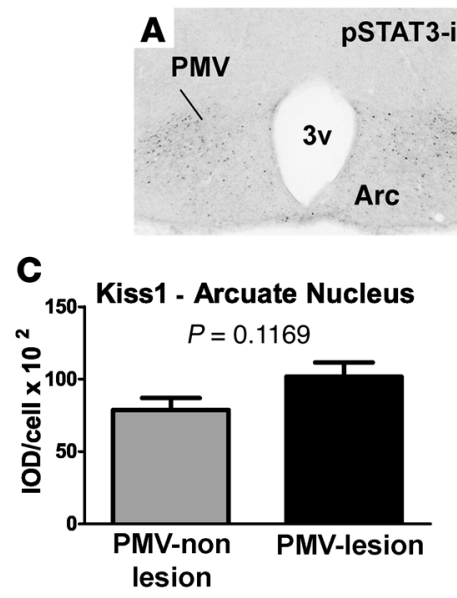

G Food intake
B PMV $Y$
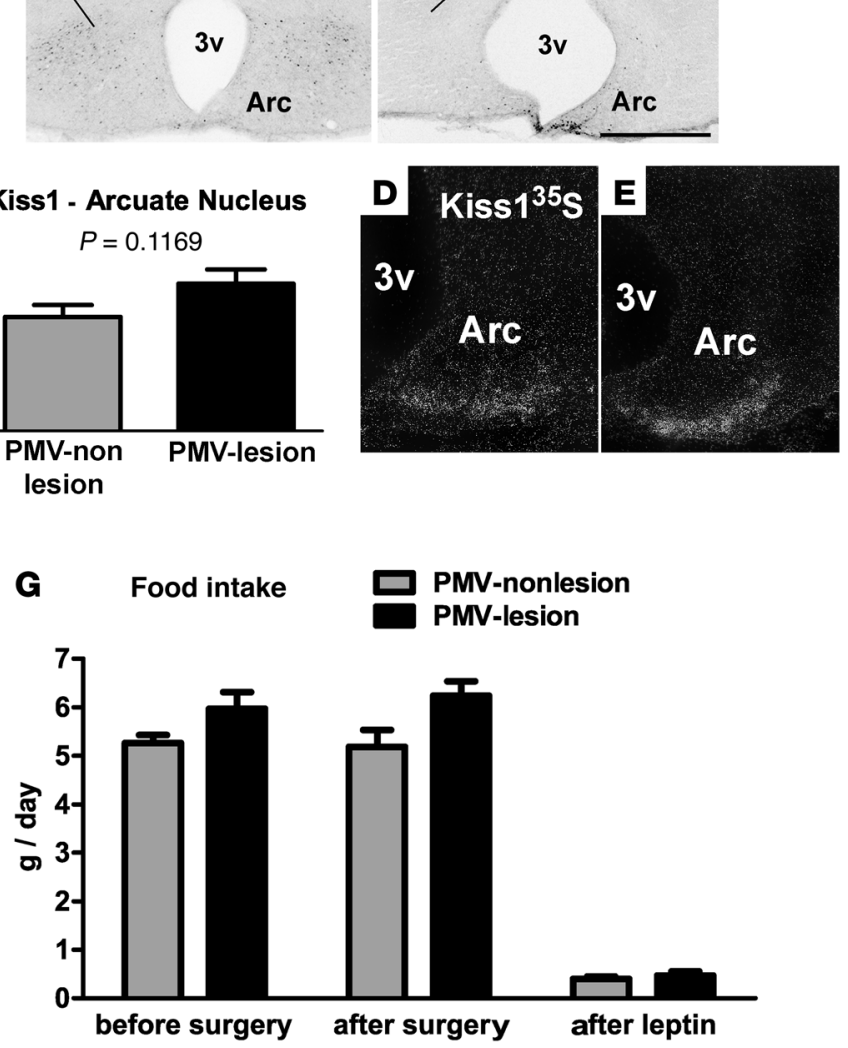

F Body weight
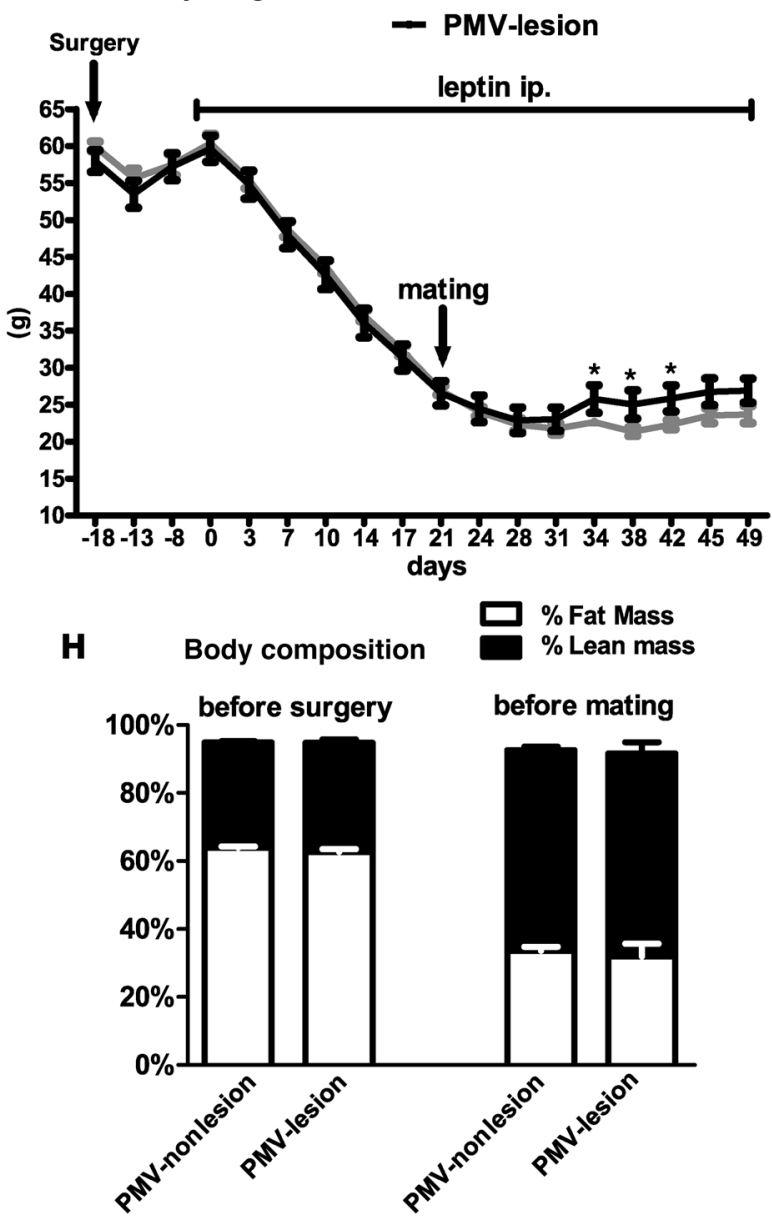

Figure 2

Bilateral lesions of the PMV did not affect leptin's effect to restore metabolic parameters in female ob/ob mice. (A and B) Distribution of pSTAT3 immunoreactivity (pSTAT3-ir) in the PMV and Arc of 1 control PMV-nonlesion mouse (A) and 1 mouse classified as PMV-lesion (B). (C) Quantification of Kiss $1 \mathrm{mRNA} /$ cell of PMV-lesion and PMV-nonlesion mice. (D and E) distribution of Kiss1 mRNA in the Arc of 1 control PMV-nonlesion mouse (D) and of 1 mouse classified as PMV-lesion (E, same case shown in B). Kiss1 expression was used to assess the extent of lesions of Arc and/or Kiss1 neurons. pSTAT3-ir and Kiss1 mRNA are intact in the Arc of PMV-lesion group. (F-H) PMV-lesion mice showed similar body weight $(\mathbf{F})$, food intake $(\mathbf{G})$ and body composition $(\mathbf{H})$ compared with control PMV-nonlesion mice before and after leptin treatment. Leptin treatment reduced food intake, body weight, and the percentage of fat mass in both groups. *Statistically different from control PMV-nonlesion ob/ob mice. $3 v$, third ventricle. Data are expressed as mean \pm SEM. Scale bars: $400 \mu \mathrm{m}$.

procedure were previously gonadectomized in order to intensify the expression of Kiss 1 mRNA in the Arc $(39,40)$. The expression of functional LepR in Kiss 1 neurons was determined by colocalization of pSTAT3 immunoreactivity in Kiss1 neurons identified by in situ hybridization (Figure 1B). Quantification of pSTAT3 immunoreactive Kiss 1 neurons revealed a reduction of $90 \%-95 \%$ in the number of leptin-responsive Kiss 1 neurons (1 or 2 duallabeled neurons/brain) in male and female Kiss1-Cre LepR ${ }^{\text {flox/flox }}$ mice compared with LepR ${ }^{\text {flox/flox }}$ littermates (Figure 1C).

Leptin signaling in Kiss 1 neurons is not required for the onset of puberty and fertility. The deleterious effect of increased adiposity on reproductive physiology is well described $(4,41,42)$. Thus, given the established role of leptin in regulating energy balance (43-46), we initially assessed whether deletion of LepR from Kiss1 neurons disrupts body weight regulation. No difference in body weights between Kiss1-Cre LepR $\mathrm{R}^{\text {flox/flox }}$ and LepR flox/flox male (Figure 1D) and female mice was observed across the experiment (18 weeks). After weaning (28 days old), female mice were monitored for vaginal opening. All Kiss1-Cre LepR flox/flox $(n=8)$ and LepR ${ }^{\text {flox/flox }}$ $(n=11)$ mice showed vaginal opening at 32 to 35 days of age (no difference between groups). At 60 days of age, females were housed with 1 sexually experienced C57BL/6 male and were monitored for fertility and fecundity. All mice were fertile and produced comparable litter sizes (Figure 1, E and F). No difference in the time for pregnancy was observed between groups. At 60 days of age, male Kiss1-Cre LepR flox/flox $(n=13)$ and LepRflox/flox mice $(n=13)$ were housed with 2 FVB females of proven fertility. All males impregnated both females except for one male Kiss1-Cre LepR flox/flox that did not impregnate the females after 8 weeks (endpoint of the experiment). No apparent deficit was observed in the reproductive tract of this male, which suggests a random phenomenon, as a $10 \%-20 \%$ infertility rate is observed in male mice with the C57BL/6 
A

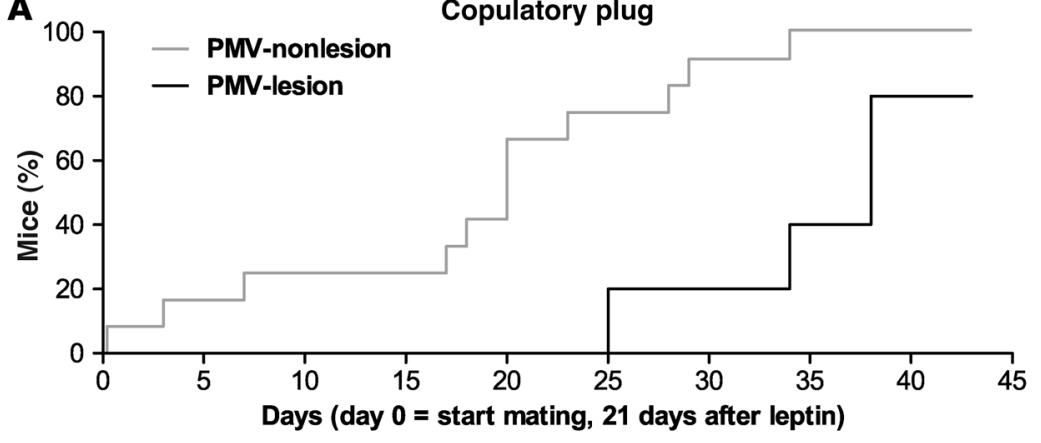

C

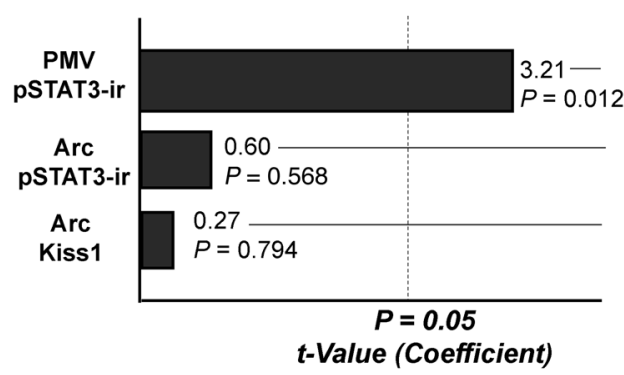

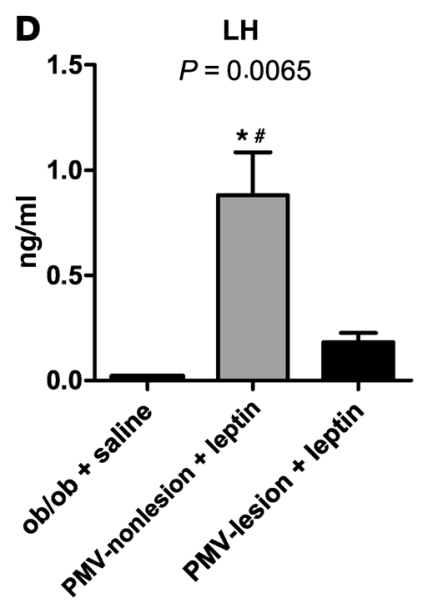

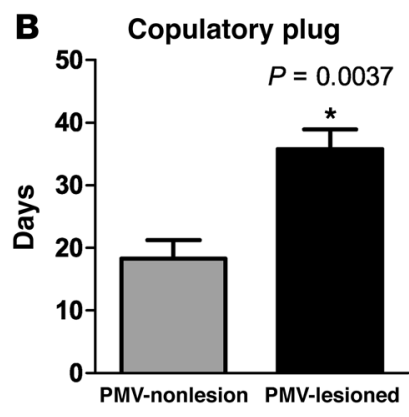

$\mathbf{E}$

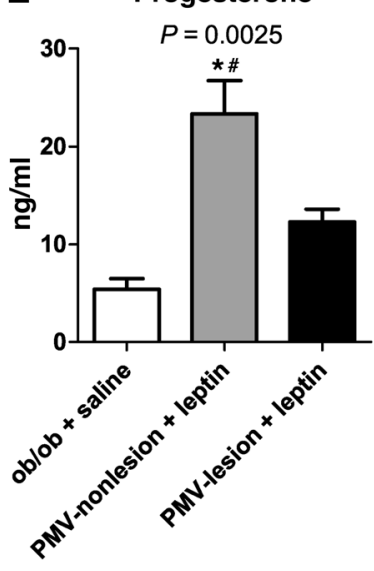

Figure 3

Bilateral lesions of the PMV-blunted leptin action to induce sexual maturation in ob/ob female mice. (A and B) Survival graph illustrating the time required for PMV-nonlesion and PMV-lesion mice to show copulatory plug in the presence of sexually experienced males. Note that the first PMV-lesion mice showed copulatory plug after 25 days with the male, while about $70 \%$ of PMV-nonlesion mice had already copulated following the same period of time. $1 \mathrm{PMV}$-lesion mouse did not show copulatory plugs until the end of the experiment (6 weeks following the intromission of the male in the cage). (C) Pareto chart of $t$ values of coefficients ( $\mathrm{df}=8$, variable: time for copulatory plug). Number of leptin-induced pSTAT3-ir in the PMV, Arc, and number of Kiss1 neurons in the Arc were assessed using a multivariate model. Note that only lesions of the PMV showed a significant coefficient. (D) Bilateral lesions of the PMV precluded leptin stimulatory effect on LH secretion in ob/ob mice. (E) PMV-lesioned mice showed decreased levels of progesterone. *Statistically different from intact ob/ob mice treated with saline. \#Statistically different from PMVlesion mice treated with leptin. Data are expressed as mean \pm SEM.

genetic background (47). Comparison among fertile males from both genotypes showed no difference in the mean time for pregnancy and mean number of offspring (Figure 1, E and F).

Bilateral excitotoxic lesions of PMV in ob/ob female mouse. In order to assess the role of PMV neurons in leptin's effects on pubertal development, we used an established experimental design in which puberty is induced and fertility rescued by giving leptin to the leptin-deficient $o b / o b$ mice $(14,15)$. Prior to leptin treatment, we performed bilateral lesions of the PMV in $o b / o b$ female mice. Lesions were accomplished by stereotaxic delivery of $\mathrm{N}$-methylD-aspartate (NMDA) (0.15 M, $100 \mathrm{nl}$ ) bilaterally into the PMV of 16 -week-old $o b / o b$ female mice $(n=24)$. NMDA is effective in inducing excitotoxic neuronal lesions without affecting fibers of passage (48). We produced 5 cases with complete bilateral lesion of the PMV, classified as "PMV-lesion" cases (Figure 2, A and B), and 12 animals with small or no lesion of the PMV, classified as "PMV-nonlesion" cases. Two rostro-to-caudal sections $(125 \mu \mathrm{m}$ interval) of the PMV, comprising the entire nucleus, were examined. We defined PMV-lesion cases as those in which fewer than 10 pSTAT3/LepR cells were identified throughout the nucleus. We also assessed possible lesions of leptin-responsive neurons in adjacent nuclei including the ventromedial nucleus of the hypothalamus (VMH), 3 rostro-to-caudal levels of the Arc, and the dorsomedial nucleus of the hypothalamus (DMH). Small or virtually no lesion of adjacent nuclei was noticed. Additionally, specifically for the Arc, we evaluated the putative lesion of Kiss1 neurons. Mice classified as PMV-lesion showed numbers of Kiss1 neurons and expression of Kiss $1 \mathrm{mRNA} /$ cell comparable to those classified as PMV-nonlesion (Figure 2, C-E).

Bilateral lesions of PMV do not prevent leptin's effects on food intake and body weight in ob/ob female mouse. We assessed food intake and body weight in PMV-lesion and PMV-nonlesion mice before and after surgery and following leptin treatment. Initial body weight and food intake were comparable between groups. After surgery, mice from both groups exhibited an expected and transient decrease in body weight (Figure 2F). After full surgical recovery (18 days), weight gain was restored in both groups and the leptin regimen was initiated. Leptin induced comparable changes in body weight in both groups (Figure 2F). After 3 weeks of leptin treatment, all mice had achieved body weights comparable to agematched WT $(26.56 \pm 1.6 \mathrm{~g}$, injected animals vs. $25.22 \pm 0.88 \mathrm{~g}$, WT). At this point, the daily dose of leptin was adjusted to $2 \mu \mathrm{g} / \mathrm{g}$. 

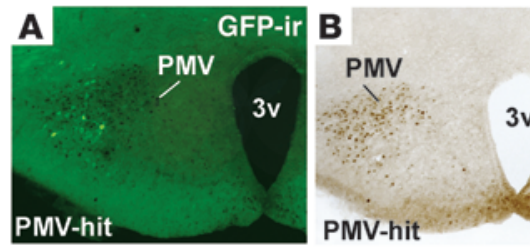

D PMV-hit CE93F

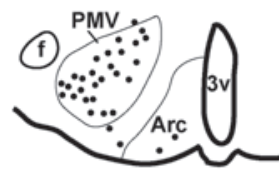

No. neurons $=705$

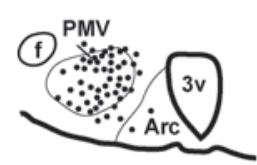

CE351F

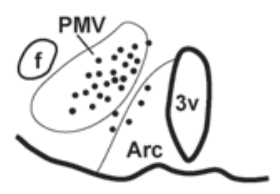

No. neurons $=\mathbf{3 5 5}$

CE386F

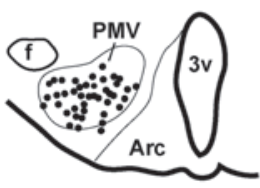

No. neurons $=325$
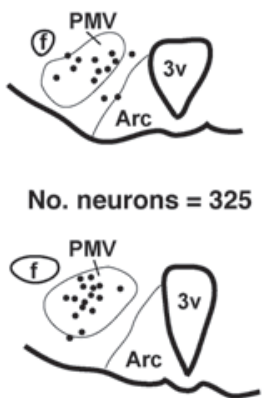

CE429F

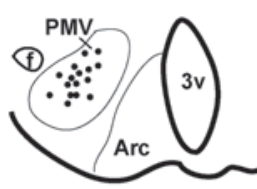

No. neurons $=135$
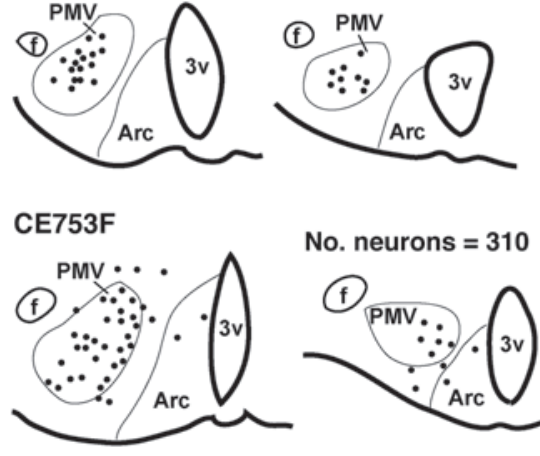

pSTAT3-ir C

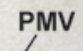

PMV

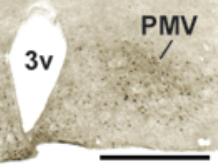

wild type

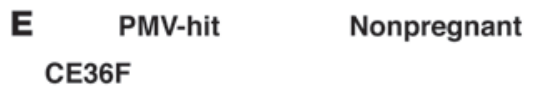

No. neurons $=395$

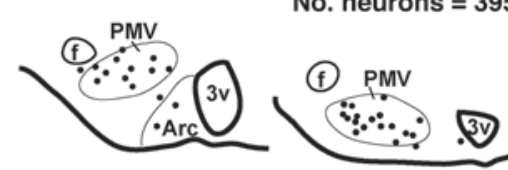

CE47F

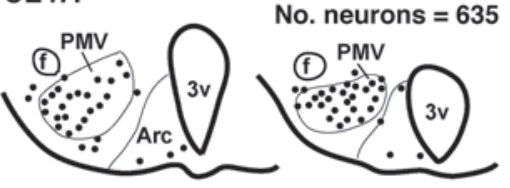

CE85F

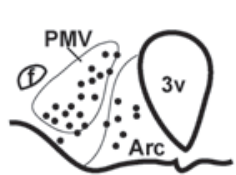

No. neurons $=\mathbf{4 0 5}$

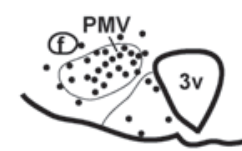

CE651F

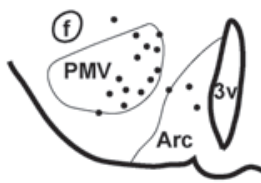

No. neurons $=135$

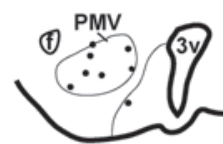

F CE343F

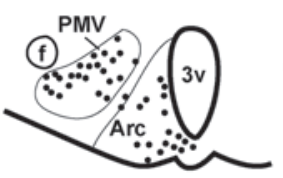

\section{Figure 4}

Distribution of neurons expressing pSTAT3 immunoreactivity in the PMV of mice classified as PMV-hits. (A and B) Example of leptin-injected PMV-hit mice showing GFP-ir (A) and pSTAT3-ir (B) as a result of unilateral LepR reactivation in the PMV. (C) Leptin-injected WT littermate for comparison of pSTAT3ir distribution. Scale bars: $400 \mu \mathrm{m}$. (D-F) Line drawings of 2 rostral-to-caudal sections of the hypothalamus at the PMV level of (D) PMV-hits that became pregnant, (E) PMV-hits that displayed vaginal opening but did not became pregnant, and (F) 1 PMV-hit that did not display vaginal opening. 1 dot represents 1 cell. f, fornix.
Only a transient difference in body weight between groups was noticed during the fifth week of leptin treatment. Lesions of the PMV caused no changes in food intake. Likewise, both groups showed similar decreases in food intake in response to leptin administration (Figure 2G). These comparable changes in body weight and food intake also produced a comparable change in body composition (Figure $2 \mathrm{H}$ ). Our findings indicate that the $\mathrm{PMV}$ is not required for leptin's effects on food intake and body weight in $o b / o b$ female mice.

Bilateral lesions of the PMV blunted leptin action to induce sexual maturation in ob/ob female mice. Leptin induced vaginal opening in all females during the first week of treatment. After 3 weeks on the leptin regimen, a sexually experienced male was introduced in the cage to test the progression of sexual maturation and the ability of the mice to copulate. Mice were monitored daily for the presence of copulatory plugs, as a sign of sexual maturity (49). After 3 weeks of mating ( 6 weeks of leptin treatment), most of the control PMV- nonlesion mice had shown copulatory plugs (67\%; Figure $3 \mathrm{~A})$. This was is in agreement with previous studies that reported copulatory plugs after 4-6 weeks of leptin treatment (15). However, no PMVlesion mice had shown copulatory plugs at the same time point. Following an additional period, PMV-lesioned mice displayed a significant delay for the presence of copulatory plugs (35.8 \pm 3.1 days) compared with nonlesioned mice (Figure 3, A and B). Of note, 1 PMV-lesioned mouse failed to show a copulatory plug after 6 weeks of mating (endpoint). Because the sizes of PMV lesions were variable and it is not possible to determine a priori the number of neurons that are necessary to maintain a specific function, we used general regression models to assess whether the time for copulatory plugs was correlated with either pSTAT3-immunoreactivity in the PMV (a measure of the number of leptin-responsive neurons remaining in the lesioned PMV), pSTAT3-immunoreactivity in the Arc or number of Kiss1 neurons in the Arc. Notably, we found that when other putative lesions are included in the multivari- 
A

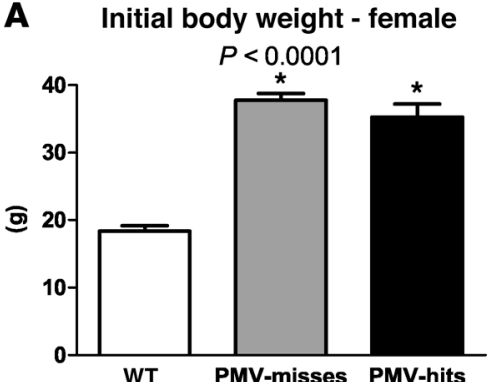

D

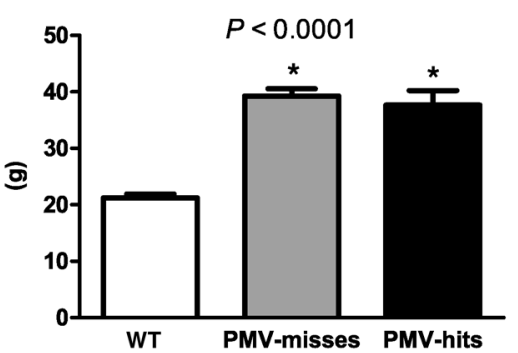

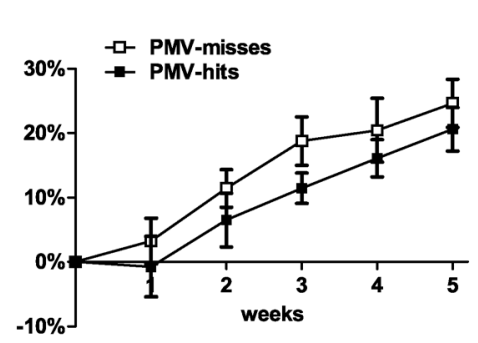

E

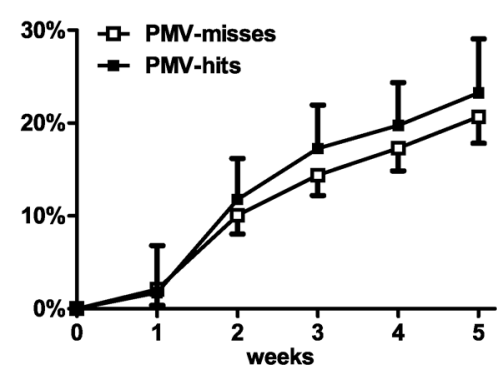

C

Food intake - female

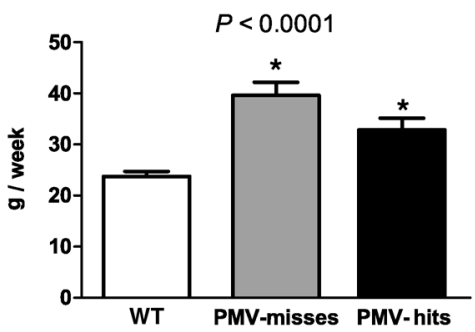

$\mathbf{F}$

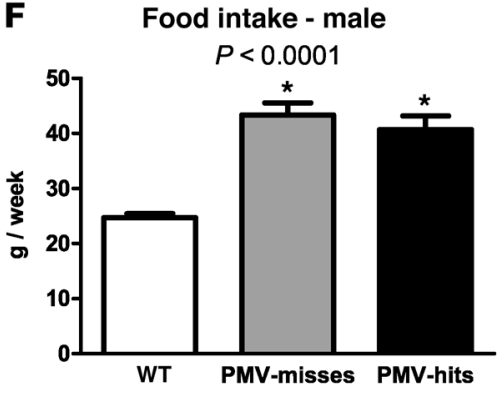

Figure 5

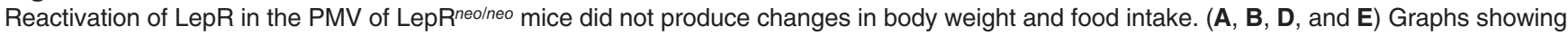
body weight of males $(\mathbf{A}$ and $\mathbf{B})$ and females $(\mathbf{D}$ and $\mathbf{E})$ LepR ${ }^{\text {neo/neo }}$ before surgery, compared with WT littermates $(P<0.0001)$, and percentage of weight gain of PMV-hits compared with PMV-misses. No difference in percentage of weight gain was observed. (C and F) Mean weekly food intake of PMV-hits and PMV-misses compared with WT littermates $(P<0.0001)$. We found no differences comparing weekly $(\mathbf{C}$ and $\mathbf{F})$ and cumulative food intake (data not shown) of PMV-hits and PMV-misses. *Statistically different compared with WT. Data are expressed as mean \pm SEM.

ate model, only lesion of the PMV shows a significant coefficient (Figure 3C). Our results indicate that PMV neurons are required for leptin-induced sexual maturation of $o b / o b$ female mice.

We also assessed the ability of leptin to induce LH secretion in leptin-deficient $o b / o b$ female mice with lesions of the PMV. After detecting the copulatory plugs, leptin regimen was ended. Following 24 to 36 hours - the period after which low to undetectable levels of circulating leptin are achieved in $o b / o b$ mice (49) - PMVlesion and PMV-nonlesion mice received a bolus of leptin i.p. $(2.5 \mu \mathrm{g} / \mathrm{g})$ at $3-5 \mathrm{pm}$ and blood was collected 40 minutes later, before perfusion. A group of intact $o b / o b$ female mice $(n=4)$ was treated with saline to serve as an additional control. Following acute leptin administration, control PMV-nonlesion $o b / o b$ mice displayed higher levels of LH compared with intact saline-treated $o b / o b$ mice (Figure 3D). However, in mice with complete bilateral lesions of the PMV, leptin treatment failed to induce LH secretion above that observed for saline-treated $o b / o b$ mice. The PMVlesioned mice also showed low levels of progesterone compared with nonlesioned mice (Figure 3E).

Reexpression of endogenous LepR in the PMV of LepR-null mice induce puberty. In order to determine whether leptin signaling in PMV neurons is sufficient for leptin's effects on puberty, we employed the Flp/FRT system to selectively restore LepR in PMV neurons in mice otherwise null for LepRs. The LepR $\mathrm{R}^{\text {neo/neo }}$ mice are homozygous for a neomycin cassette flanked by FRT sites targeted to the Lepr locus $(35,50)$. These mice recapitulate the LepR-deficient phenotypes and therefore are obese, diabetic, and infertile. We performed unilateral stereotaxic injection of an adeno-associated virus vector expressing Flp recombinase (AAV-Flp) into the PMV of adult LepR ${ }^{\text {nеo }}$ neo male and female mice. The viral vector is an
AAV-Flp-IRES-eGFP construct designed so that Flp and GFP are driven by CMV regulatory elements, allowing the visualization of the injection sites using GFP immunoreactivity (50).

Prior to brain injections, LepR ${ }^{\text {neo/neo }}$ male $(n=21)$ and female $(n=23)$ mice and WT littermates ( $n=6$ males and $n=6$ females) were housed with opposite sex, sexually experienced WT C57BL/ 6 mice, starting at 4-5 weeks of age. After 6 weeks, none of the LepR ${ }^{\text {neo/neo }}$ male mice showed fertility and none of the female mice displayed progressive vaginal opening at 67-72 days of age. In comparison, all WT littermates were sexually mature and fertile at the same age. The AAV-Flp injections were performed in adult (67-72 days old) LepR ${ }^{\text {neo/neo }}$ mice ( $n=21$ males and $n=23$ females) and sexually naive WT littermates ( $n=4$ males and $n=6$ females). Additional control groups consisted of LepR $\mathrm{R}^{\text {neo/neo }}$ mice that had received stereotaxic injections of AAV-GFP into the PMV.

In order to identify the exact sites of functional LepR reactivation, before sacrifice all animals were fasted for 24 hours and treated with leptin i.p. Sites of reactivation were identified by the presence of GFP and PSTAT3 immunoreactive neurons. We produced 11 males and 10 females with injections of AAV-Flp centered in the PMV (classified as PMV-hits; Figure 4). In 10 males and 13 females, the injections were not located in the PMV but in adjacent nuclei including the $\mathrm{DMH}(n=2$ males and $n=3$ females), the $\operatorname{Arc}(n=3$ males and $n=4$ females), and surrounding regions of the hypothalamus that do not express LepR $(n=5$ males and $n=6$ females). These mice were classified as PMV-misses and were considered anatomic controls.

Reactivation of LepR in PMV neurons of LepR-null mice causes no change in body weight and food intake. As described in previous experiments, we also assessed food intake and body weight in PMV-hits com- 
A

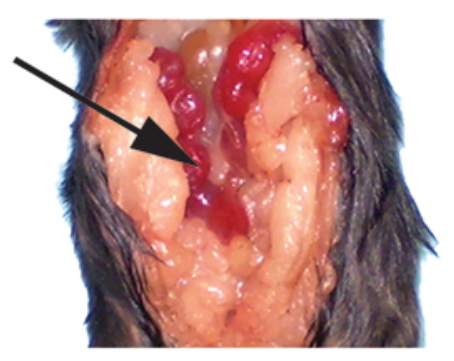

C Uterus

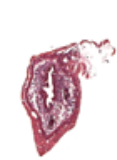

PMV-miss

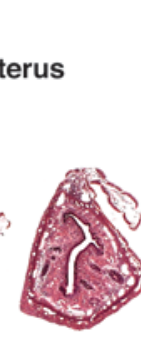

PMV-hit

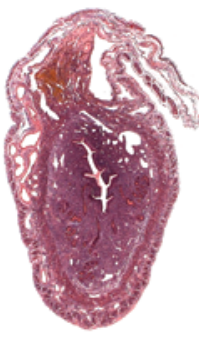

PMV-hit after pregnancy

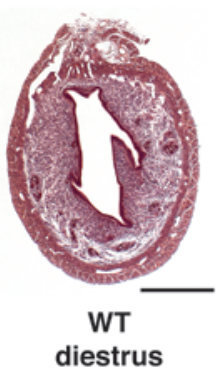

B

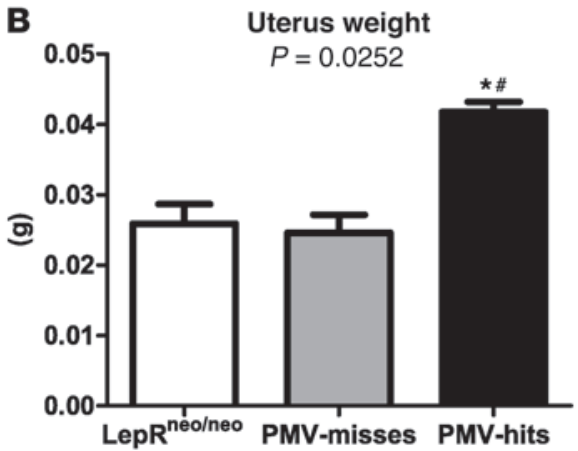

D

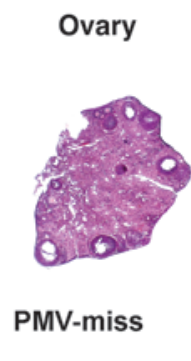

PMV-hit

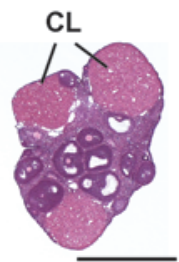

Figure 6

Reactivation of LepR in the PMV of LepR ${ }^{\text {neo/neo }}$ mice induces puberty. (A) Detail of the abdominal cavity of a PMV-hit that became pregnant perfused soon after body weight loss. Observe the amount of visceral fat depots characteristic of LepR-null mice and the uterus with implantations (arrow). Subdiaphragmatic digestive tract was removed. (B) PMV-hits displayed an increased uterus weight compared with PMV-misses and intact LepR ${ }^{\text {neo/neo }}$ age-matched mice $(P=0.0252)$. (C) Uterine transversal sections of a PMV-miss, of a PMV-hit that displayed vaginal opening, of a PMV-hit that became pregnant after miscarriage, and of a WT C57BL/6 mouse perfused on diestrus, for comparison. (D) Ovarian transversal sections of a PMV-miss and a PMV-hit. Observe the presence of corpora lutea (CL) only in the ovary of the PMV-hit. *Statistically different from

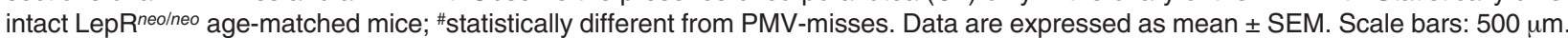

pared with PMV-misses and WT littermates. The PMV-misses with contamination of the Arc were not included in our analysis, as these mice showed the expected decrease in food intake and body weight $(50,51)$. We found that selective reexpression of LepRs in the PMV (PMV-hits, $n=11$ males and $n=7$ females) induced no changes in food intake and body weight compared with PMV-misses (Figure 5, $\mathrm{A}$ and $\mathrm{F}$ ). In this analysis, PMV-misses consisted of mice with AAVFlp injected in areas that do not express LepR $(n=5$ males and $n=6$ females). PMV-misses with contamination of the DMH were analyzed separately, as the role played by leptin-responsive cells in the $\mathrm{DMH}$ is not fully understood. We also found no difference between PMV-hits and DMH-injected mice ( $n=3$ males and $n=3$ females).

Reactivation of LepR in PMV neurons induces puberty and improves fertility of LepR-null female mice. Ten weeks following AAV-Flp injections, the female mice with AAV-GFP injections in the PMV $(n=3)$ or those with AAV-Flp injections that missed the PMV displayed virtually no or very small and rounded vaginal opening. In marked contrast, we found that 9 of 10 PMV-hits displayed an unambiguous and progressive vaginal opening. The specific timing of vaginal opening varied from case to case. Two mice showed vaginal opening at 3 weeks after injection, 3 mice at 4 weeks, 2 mice at 5 weeks, and 2 mice at 6 weeks. The vaginal cytology assessed for 2 weeks also varied from case to case. For example, 2 mice showed a persistent diestrus (10-12 days), 2 mice a persistent estrus (8-10 days), and the others showed variable and inconsistent cycles. All PMVreactivated mice (PMV-hits) showed at least 2 episodes of vaginal cornification during the period analyzed ( 2 weeks), indicating progression of sexual maturation (52).
To further characterize the sexual maturity and changes in fertility induced by endogenous LepR reexpression in the PMV, females were housed with sexually experienced C57BL/6 male mice. Remarkably, during a period of 6 weeks, we found that 5 of the mice classified as PMV-hits became pregnant. These mice displayed an increase in body weight and abdominal dilation 4-5 weeks after the introduction of the male in the cage. However, 4 of these 5 cases did not carry pups to term. One case successfully delivered pups ( 5 in the litter) that died soon after birth without milk in their stomachs. Three of the mice that did not deliver pups were perfused as soon as consistent weight loss due to pregnancy failure was observed. We confirmed pregnancy by collecting the uteri and analyzing the occurrence of implantations (Figure 6A). The number of implantations in these cases was comparable to that observed in pregnant WT C57BL/6 females (6 to 8).

In order to assess changes in the maturation of reproductive organs, we additionally collected the uteri and ovaries of intact

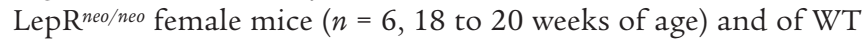
littermates on diestrus $(n=7,18-20$ weeks of age). As observed in leptin-signaling-deficient mice $(14-15,53,54)$, LepR ${ }^{\text {пеo/nеo }}$ mice displayed significantly lower uterine weight compared with WT $(0.0259 \pm 0.003$ g vs. $0.074 \pm 0.006$ g,$P<0.0001)$. Subsequently, in order to assess whether PMV-hits that displayed vaginal opening but did not become pregnant showed any progress in sexual maturation, we compared their uterine weight with that of intact $\mathrm{LepR}^{\text {nеo/neo }}$ and PMV-misses. We found no difference in uterine weight between intact LepR ${ }^{\text {nеo/neo }}$ and PMV-misses. However, we observed that PMV-hits exhibited a significant increase in uter- 

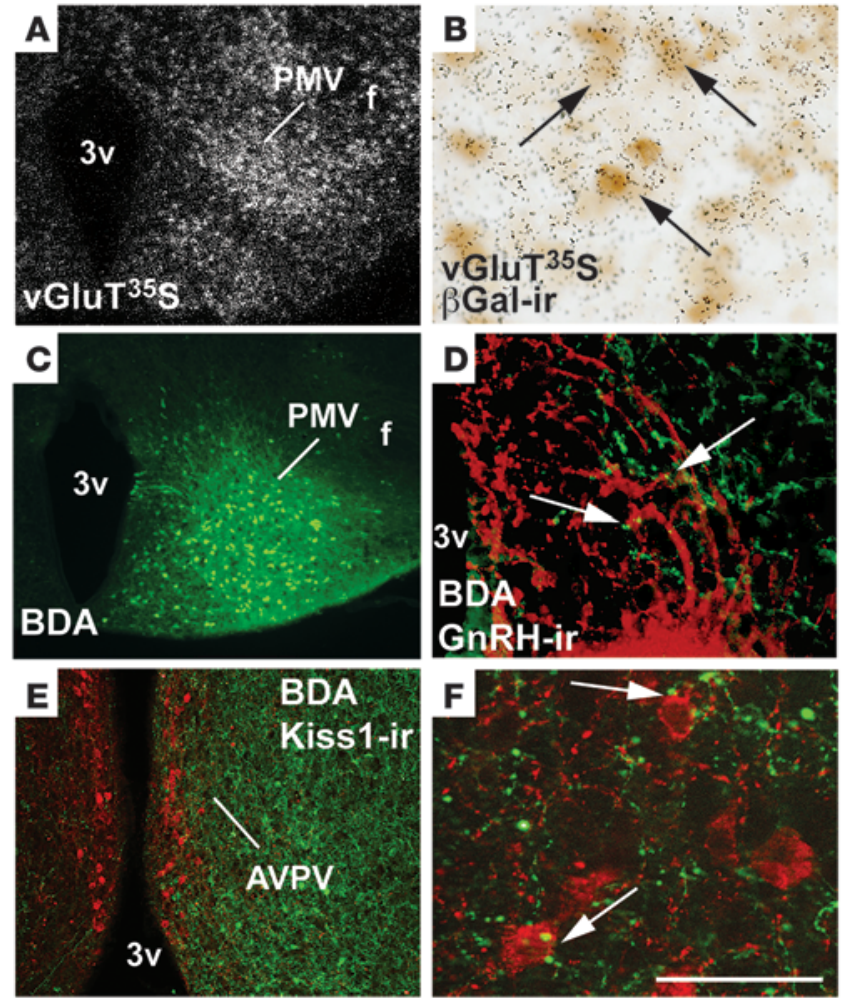

\section{Figure 7}

Neurons in the PMV coexpress glutamate and LepR and make apparent contacts with Kiss 1 neurons and GnRH terminals. (A) Distribution of vesicular glutamate transporter 2 (vGluT2) mRNA in the PMV of LepR-cre LacZ (reporter) female mice. (B) PMV neurons coexpress vGluT2 mRNA (silver grains, ${ }^{35}$ S-labeled riboprobe) and $\beta$-gal immunoreactivity ( $\beta$-gal-ir, brown cytoplasm, arrows). (C) Injection site of the anterograde tracer BDA into the PMV. (D) BDA fibers (green) in close apposition to $\mathrm{GnRH}$ immunoreactive fibers (red) in the median eminence/mediobasal hypothalamus (arrows). (E) Innervation of the anteroventral periventricular nucleus (AVPV) by PMV neurons; (F) close appositions (arrows) between fibers originating from PMV neurons (in green) and Kisspeptin immunoreactive (Kisspeptin-ir) neurons of the AVPV (in red). Scale bars: $400 \mu \mathrm{m}$ (A, C, E); $80 \mu \mathrm{m}$ (B and D); $50 \mu \mathrm{m}$ (F).

ure 1A; supplemental material available online with this article; doi:10.1172/JCI45106DS1). Additionally, compared with WT, LepR ${ }^{\text {neo/neo }}$ showed only a tendency for a decrease in testis weight $(P=0.0613$; Supplemental Figure 1B). We also compared the seminal gland and testis weight of the intact LepR $\mathrm{R}^{\text {neo/neo, }}$, the PMV-hits, and the PMV-misses. We found no differences comparing all groups ( $P=0.3878$ for seminal vesicle weight and $P=0.7045$ for testis weight; Supplemental Figure 1, C and D). We then assessed testis histology and found no identifiable morphological changes comparing PMVmisses, PMV-hits, and WT (Supplemental Figure 1, E-J).

As mentioned, in order to identify the sites of reactivation, the PMV-hits, PMV-misses, and WT littermates were perfused after fasting, a condition known to decrease gonadotropins and testosterone levels $(57,58)$. In agreement, mice displayed comparable low levels of testosterone (WT: $29.48 \pm 9.9 \mathrm{ng} / \mathrm{dl}$; PMV-misses: $38.47 \pm 5.9 \mathrm{ng} / \mathrm{dl}$; PMV-hits: $34.52 \pm 5.1 \mathrm{ng} / \mathrm{dl}, P=0.7060$ ), except for 1 fertile PMVhit which showed high testosterone level $(279.87 \mathrm{ng} / \mathrm{dl})$. It is well reported that a small percentage of leptin-deficient male mice are fertile (59). Therefore, our findings indicate that no clear or significant improvement of the reproductive physiology of the LepR-null male mice was attained following reexpression of LepR in the PMV.

Leptin-responsive PMV neurons coexpress glutamate and innervate Kiss1 neurons and GnRH terminals. An increase in excitatory inputs and/or in sensitivity of glutamate receptors of GnRH neurons is a key event at the onset of puberty and at the time of the preovulatory LH surge (60-63). Thus, in order to determine whether PMV neurons coexpress LepR and glutamate, we performed colocalization studies in a mouse model carrying a LepR-dependent reporter gene. Mice expressing Cre under the control of the endogenous Lepr promoter (LepRb-IRES-Cre mice) (64) were crossed to mice carrying a Cre-inducible LacZ allele. In our reporter mice (LepR-LacZ), virtually all $\beta$-gal immunoreactive neurons in the PMV expressed pSTAT3 following leptin administration (38). We found that $93.9 \% \pm 0.5 \%$ of PMV neurons that express $\beta$-gal immunoreactivity coexpress vesicular glutamate transporters ( $v$ GluT2) mRNA (Figure 7, A and B).

To assess whether PMV neurons innervate GnRH terminals and/or Kiss1 neurons, we injected male and female C57BL/6 mice with the anterograde tracer biotin dextran amine (BDA) (Figure 7C). Using a high-resolution microscope with a Z-stack module allowing $3 \mathrm{D}$ reconstruction of $1-\mu \mathrm{m}$ optical sections (ApoTome Microscope, AxioVision software; Zeiss), we observed PMV fibers in close apposition with GnRH terminals in the median eminence/ mediobasal hypothalamus and with Kiss1 neurons in the AVPV (Figure 7, D-F). 
A GnRH mRNA - female
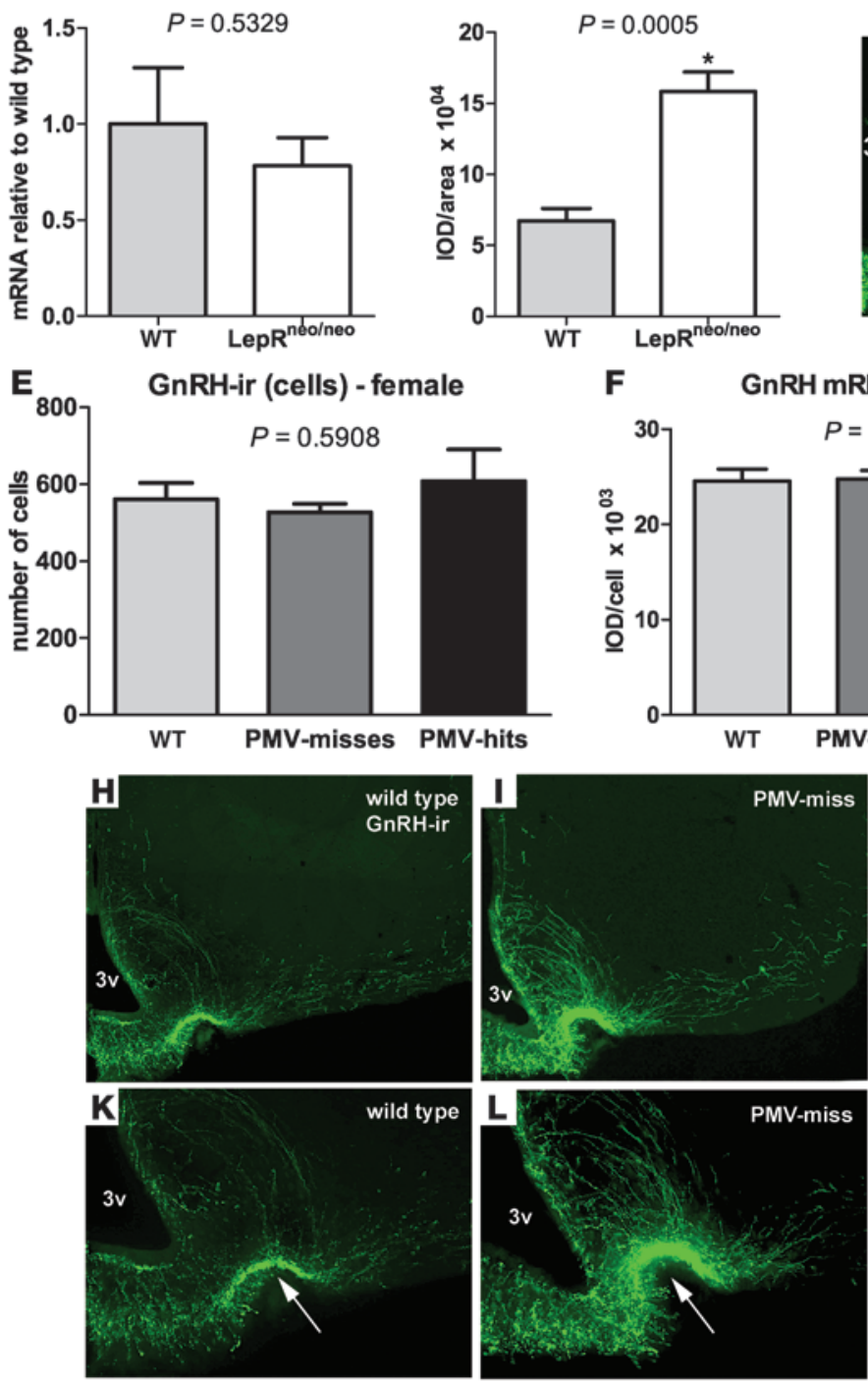

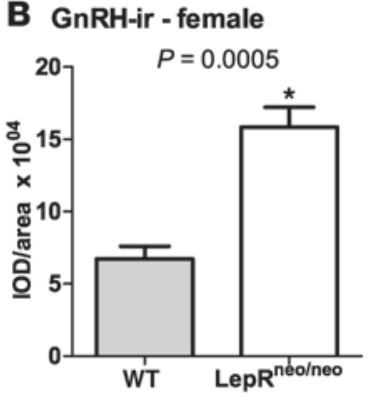

$\mathbf{F}$
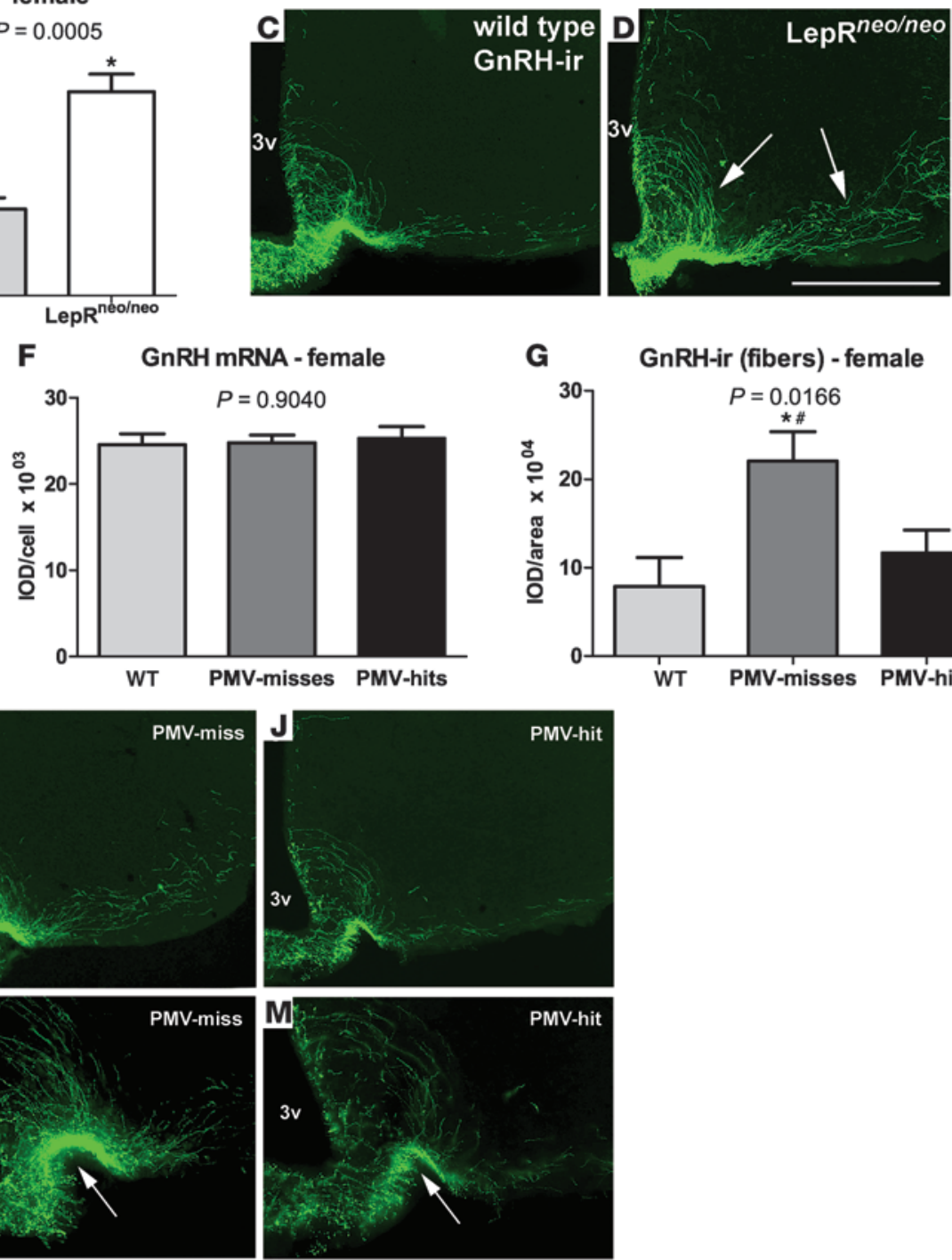
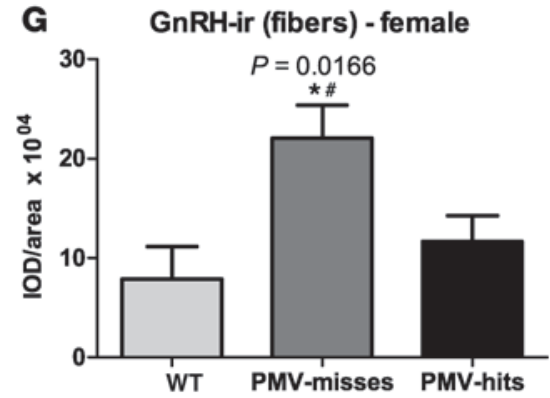

Figure 8

Reactivation of LepRs in the PMV normalizes the increased GnRH content in the median eminence/medial basal hypothalamus characteristic of LepR-null mice. (A-D) LepR ${ }^{\text {neo/neo }}$ female mice show equivalent $\mathrm{GnRH}$ gene expression but increased $\mathrm{GnRH}$ immunoreactivity (GnRH-ir) in the median eminence/mediobasal hypothalamus compared with WT (arrows indicate GnRH fibers descending through the periventricular tract and medial forebrain bundle). (E-M) Endogenous reexpression of LepR in the PMV normalizes the increased GnRH-ir observed in LepR higher magnifications of $\mathbf{H}-\mathbf{J}$ (arrows indicate the lateral palisade layer of the median eminence, where GnRH fibers are enriched). *Statistically different from WT; "statistically different from PMV-hits. Data are expressed as mean \pm SEM. Scale bars: $400 \mu \mathrm{m}(\mathbf{C}, \mathbf{D}$ and $\mathbf{H}-\mathbf{J}) ; 200 \mu \mathrm{m}(\mathbf{K}-\mathbf{M})$.

PMV action mediating leptin's effect on reproduction is independent of changes in Kiss 1 expression. Because the PMV densely innervates the AVPV and apparently Kiss1 neurons, we assessed whether the rescue of the reproductive phenotype of LepR-null mice by reexpression of LepR in the PMV is consequent to changes in Kiss 1 gene expression. We initially assessed whether Kiss 1 mRNA expression is different, comparing C57BL/ 6 WT ( $n=4$ females, 18 to 20 weeks of age) and intact LepR ${ }^{\text {neo/neo }}$ female mice ( $n=4$ females, 18 to 20 weeks of age). We found no difference in Kiss 1 mRNA (total area and individual cells) or in the number of Kiss1 neurons in the female AVPV (Supplemental Figure 2, A-C). In the female Arc, we did not find differences in total Kiss1 mRNA or the number of Kiss 1 neurons (Supplemental Figure 2, $\mathrm{E}$ and $\mathrm{G})$. However, as shown in leptin-deficient $o b / o b$ male mice (28), we did observe a decrease in Kiss1 mRNA/cell in the Arc of LepR ${ }^{\text {neo/neo }}$ female mice $(P=0.0065$; Supplemental Figure 3F). We then assessed whether reactivation of LepR in the PMV caused changes in Kiss1 mRNA/cell. We found no difference in Kiss $1 \mathrm{mRNA} /$ cell in the AVPV or the Arc comparing PMV-misses and PMV-hits (Supplemental Figure 3). In males, only the Arc was assessed due to the sexually dimorphic nature of Kiss1 in the AVPV $\left(n=4\right.$, WT and $n=5$, LepR ${ }^{\text {пео } / \text { пеo })}$ $(39,40,65)$. No difference in Kiss 1 gene expression (total area or individual cells) or number of cells was detected in LepR ${ }^{\text {nеo/neo }}$ male mice compared with WT male mice (Supplemental Figure 2, H-J) or between PMV-misses and PMV-hits. Our findings indicate that leptin action on PMV neurons to rescue the reproductive deficits of LepR-null mice is independent of changes in Kiss1 gene expression. 
Reexpression of LepR in the PMV normalized GnRH content in the median eminence/mediobasal bypothalamus of LepR-null female mice. To further test our model, we assessed changes in the GnRH neuronal system in LepR-null and reactivated mice. We initially assessed possible differences in localization and number of GnRH neurons as well as $\mathrm{GnRH}$ gene expression comparing C57BL/6 WT $(n=4$ males and $n=4$ females, 18 to 20 weeks of age) and intact LepR ${ }^{\text {neo/neo }}$ male and female mice ( $n=5$ males and $n=4$ females, 18 to 20 weeks of age). In LepR ${ }^{\text {neo/neo }}$ male and female mice, as in WT, GnRH neurons were distributed in the medial septal nucleus, in the preoptic area, surrounding the vascular organ of lamina terminalis, and scattered in the ventral aspect of the anterior hypothalamic area. No apparent deficit in GnRH neuron migration was noticed in LepR $\mathrm{R}^{\text {neon }}$ eo mice. We also found no changes in GnRH mRNA expression (Figure 8A and Supplemental Figure 4A) or number of $G n R H$ neurons (males: $740.0 \pm 15.00$ neurons in WT vs. $778.8 \pm 25.36$ neurons in LepR ${ }^{\text {neo/neo }}, P=0.3782$; females: $775.0 \pm 52.95$ neurons in WT vs. $669.0 \pm 49.31$ neurons in $\mathrm{LepR}^{\text {nеo/neo }}, P=0.1833$, in 1 series of sections). However, we found increased GnRH content (observed via immunoreactivity) in the median eminence/mediobasal hypothalamus of LepR ${ }^{\text {пео } / \text { по }}$ female mice compared with WT on diestrus (Figure 8, B-D). No difference in GnRH content between male $\mathrm{LepR}^{\text {neo/neo }}$ and WT mice was noticed (Supplemental Figure 4, B-D).

We then assessed whether reactivation of LepR in PMV neurons induced changes in GnRH expression or peptide content. Because states of negative energy balance may increase GnRH immunoreactivity (66), we compared PMV-misses, PMV-hits, and WT littermates. As mentioned, these mice were fasted for 24 hours before perfusion. We found no changes in the number or in the amount of GnRH mRNA/cell of females comparing all groups (Figure 8, E and F). However, PMV-misses displayed increased GnRH immunoreactivity at the median eminence/mediobasal hypothalamus compared with WT $(P=0.0166$; Figure 8, G-I). Remarkably, PMV-hits showed a comparable amount of GnRH immunoreactivity to WT (Figure 8, G-M), suggesting that the reactivation of LepR selectively in PMV neurons stimulates GnRH release and, therefore, normalizes the GnRH content in the median eminence/mediobasal hypothalamus of female LepR-null mice.

\section{Discussion}

It has been known for decades that nutritional state affects puberty and the reproductive status in many species, including humans $(1,2)$. Sexual maturation is usually initiated when energy stores meet the demands of the reproductive function including the production of hormones and gametes, copulation, pregnancy, and lactation. If excessive leanness occurs in young women, puberty is often delayed (2). Moreover, the existence of a link between the advance of childhood obesity and the increasing rates of precocious puberty has also been postulated. A previous study published in 1997 reported that, in the USA, $6.7 \%$ of girls had clinical evidence of puberty at age 7 years and $14.7 \%$ at age 8 years. Authors also described the youngest population age at puberty onset as $9.9 \pm 1.8$ years (8). In the last decade, an increment of $5 \%-8 \%$ in the number of girls with clinical evidence of puberty at age 7 and 8 years has been reported (5). The cause for this alarming phenomenon is not quite understood. One possibility is the increased levels of circulating leptin in obese children. Increased adiposity is often correlated to high leptin levels $(67,68)$, a condition known to accelerate pubertal development $(69,70)$. However, the sites of leptin action on puberty initiation and therefore the mechanisms by which this physiological event is regulated have been difficult to determine.
The role played by the Kiss1/Kiss1r system in puberty and fertility has been well described. Loss-of-function mutations of Kiss1 or Kiss1r genes in rodents and humans result in hypogonadism, abnormal sexual maturation, and decreased circulating levels of sex steroids and gonadotropins (71-74). Administration of Kisspeptin to juvenile rodents induces vaginal opening, increases LH secretion, and induces ovulation $(75,76)$. Hypothalamic levels of Kiss 1 and Kiss Ir mRNAs and electrophysiological responses of GnRH neurons to Kisspeptin increase across puberty $(76,77)$. Collectively, these findings indicate that Kiss 1 neurons play an essential role in pubertal development, but what triggers the Kiss1/Kiss1r system is still unsettled. Leptin has been a plausible candidate, and therefore, leptin-responsive Kiss 1 neurons would be well positioned to relay leptin's effect on puberty initiation. To test this model, we generated mice with selective deletion of LepR from Kiss1 neurons and assessed their sexual maturation. We found that male and female mice progress through puberty normally and are fertile, suggesting that leptin signaling in Kiss1 neurons is not required for pubertal development and fertility. Studies from different laboratories have shown that kisspeptin induces $\mathrm{LH}$ secretion via direct stimulation of GnRH neurons $(75,78-81)$. But the estrogen-induced LH surge still occurs in Kiss1r-knockout mice, suggesting the existence of an additional relevant pathway in the regulation of GnRH-induced LH secretion (82). Our findings are in agreement with this concept and indicate that leptin's effect in the onset of puberty is relayed by an alternative route outside Kiss 1 neurons. Nevertheless, the physiologic relevance of direct leptin signaling in Kiss1 neurons in different paradigms is yet to be determined, as developmental adaptations may have occurred in our mouse model.

The role played by PMV neurons in mediating leptin's effects has been largely ignored. The PMV neurons express sex steroid receptors $(83,84)$ and are activated following copulation or exposure to sexually relevant odors (85-91), but its role in pubertal development had not been anticipated. In fact, the lack of mouse models in which to selectively manipulate LepR in the PMV represents an additional difficulty in assessing the physiological role played by PMV neurons. In this study, we employed stereotaxic techniques to lesion PMV neurons of $a b / o b$ mice or to reactivate endogenous expression of LepR in PMV neurons of LepR-null mice. These techniques inherently produce heterogeneous experimental subjects due to variable injection sizes and injection sites. Moreover, in order to precisely determine the functional reactivation of LepR or lesion of neurons that express LepR, mice were fasted to potentiate leptin-induced PSTAT3-ir. This precluded a systematic analysis of their hormonal profile and evaluation of differential reproductive parameters. However, our results are unambiguous. We identified the PMV as a key site of leptin action in the onset of puberty. Reexpression of LepR in adjacent sites outside the PMV did not trigger pubertal development in LepR-null mice. Likewise, partial lesion of the PMV or of neurons outside the PMV did not blunt leptin's effect of inducing sexual maturity in $o b / o b$ female mice.

Previous studies have suggested that leptin plays a small or virtually no role in the progress of pregnancy (92). Therefore, we established the copulatory plugs as the endpoint for the lesion experiment. In this experimental design, we also assessed leptin's effect on LH secretion. Leptin treatment prevents the fall in LH levels during states of negative energy balance, when leptin levels are low $(34,58,93-96)$. As previously demonstrated $(14,54)$, all intact $o b / o b$ female mice exhibited low levels of $\mathrm{LH}$, which were increased following leptin administration. However, leptin was ineffective at increasing LH levels in PMV- 
lesioned $o b / o b$ mice. These findings confirm and extend previous data (34) indicating that PMV is also required for leptin's stimulatory effect on LH secretion in leptin-deficient $o b / o b$ mice. During proestrus, the increase in LH levels also stimulates progesterone production, which in turn is essential for copulatory behavior $(97,98)$. Following copulation, female rodents display a sustained increase in progesterone as a result of neuroendocrine reflex generated by vaginal-cervical stimulation (99). Therefore, the low levels of progesterone observed in PMVlesioned mice may be a consequence of the decreased LH secretion and/or may indicate a deficient copulatory behavior in these mice.

Selective reexpression of LepR in PMV neurons induced puberty and sexual maturation in a high percentage of LepR-null female mice. Remarkably, this effect was independent of changes in body weight or food intake. Thus, endogenous reexpression of LepR in the PMV did not correct the obese phenotype and likely did not rescue most of the endocrine dysfunctions of LepR-null mice. This is worth emphasizing, as most of the pregnant females underwent miscarriages. It is now well documented that obesity as well as diabetes may increase the probability of miscarriage and malformations in rodents and humans (100-102). Therefore, the miscarriages and the absence of pregnancy in some of the reactivated mice may be caused by the remaining metabolic or endocrine abnormalities following reactivation of LepR in PMV neurons of LepR-null mice.

Deficits in gonadal development of leptin-deficient $o b / o b$ male mice are well described $(14,16,54)$. In contrast, and in agreement with our findings, the absence of a clear morphological abnormality in the reproductive tract of LepR-deficient male mice has also been reported by others $(53,103)$. But intriguingly, reexpression of LepR in the PMV of LepR-null mice did not ameliorate male fertility. This may indicate that the sites of leptin action in the reproductive physiology of rodents are sexually dimorphic. The generation of mouse models to specifically manipulate genes of interest in PMV neurons will allow further evaluation of the contribution of leptin signaling in PMV neurons to male sexual maturation and also to female pregnancy.

In the present study, we demonstrate that leptin's effect in pubertal development is relayed by PMV neurons expressing the excitatory neurotransmitter glutamate. Leptin directly depolarizes PMV neurons (89), which may, in turn, "activate" their downstream neuronal targets, including GnRH cell bodies in the preoptic area $(89,104,105)$ and/or GnRH terminals in the median eminence/mediobasal hypothalamus. This model is in agreement with a recent study that reported that glutamate stimulates GnRH secretion in the absence of the Kiss1/Kiss1r system (106). Thus, our findings indicate that PMV neurons may serve as an alternative pathway in this circuitry, conveying inputs on changing levels of leptin directly to GnRH neurons. As observed in $d b / d b$ and $o b / o b$ mice $(53,54)$, LepR-null mice displayed no deficits in GnRH neuronal migration, GnRH gene expression, or peptide production. We also noticed that LepR-null mice show modest or undetectable changes in Kiss1 gene expression compared with control littermates. Together, these data suggest that the infertility phenotype of the LepR-null mice is not caused by deficient expression of Gnrb or Kiss 1 genes. Rather, the leptin-signaling deficient mice display increased GnRH content in the median eminence/mediobasal hypothalamus, strengthening the model that GnRH secretion is inhibited in females with leptin-signaling deficiency $(53,54)$. This elevated GnRH content is not observed in the infertile Kiss1 gene knockout mice $(73,74)$, suggesting that the disruption in the normal pubertal development observed in Kiss 1 and in leptin-signaling deficiencies is caused by dissociated mechanisms. Importantly, reexpression of LepR in PMV neurons of LepR-null mice normalizes their
GnRH content in the median eminence/mediobasal hypothalamus. This is in concert with the well-established concept acquired from studies conducted in vivo and in vitro, in different species and sexes, that leptin acts in the brain stimulating GnRH secretion (107-111). Although the bulk of evidence collected in the present study favors a direct action of PMV neurons in GnRH terminals, we cannot rule out the existence of additional and/or alternative relays. In many physiological systems and, in particular, in the reproductive function, redundant pathways are essential for species survival. Here, we demonstrate that a direct action of leptin on PMV neurons is required and sufficient for leptin's effect in the onset of puberty. But it is not clear whether glutamatergic PMV neurons exert their role by directly stimulating GnRH secretion or by acting in an additional relay (e.g., kisspeptin neurons) that impinges on GnRH neurons. In any case, the hypothalamic circuitry (i.e., GnRH and Kiss1 neurons) must be in place to provide the underlying substrate for leptin's effect as a "permissive" factor in the onset of puberty.

The role played by leptin as a permissive factor for the onset of puberty is well determined. But the efforts to dissect the effects of leptin and the mechanisms by which puberty is initiated have been obstructed by the lack of information on where in the brain this effect takes place. Our study establishes the PMV as a key site for leptin action in the onset of puberty and demonstrates that direct leptin signaling in Kiss1 neurons is not required for pubertal development and fertility. Our findings also add to the growing literature suggesting that leptin's multiple actions to control metabolism and reproduction are anatomically dissociated.

\section{Methods}

Mice. Adult male and female Kiss1-Cre, LepR ${ }^{f l o x} / f l o x$, LepR ${ }^{\text {neo/neo }}$, LepR-IRESCre, $\beta$-gal reporter/B6.129S4-Gt(ROSA)26-Sortm1Sor/J (Jackson Labs), and $\mathrm{C} 57 \mathrm{BL} / 6$ mice and female $o b / o b$ mice were housed in the University of Texas Southwestern Medical Center Facility. All animal studies were approved by the University of Texas Southwestern Medical Center Institutional Animal Care and Use Committee, Dallas, Texas, USA.

Stereotaxic injections. We performed stereotaxic injection of BDA unilaterally in the PMV of WT mice, of NMDA ( $0.15 \mathrm{M}$, Sigma-Aldrich) bilaterally into the PMV of $o b / o b$ female mice, and of adeno-associated virus vector (AAV-Flp or AAV-GFP) unilaterally into the PMV of male and female LepRnull mice. Mice were housed individually after surgery. Before sacrifice, AAV-Flp-injected mice, AAV-GFP-injected mice, and NMDA-injected mice were fasted for 24 hours and received i.p. leptin 40 minutes before perfusion (provided by A.F. Parlow, Harbor-UCLA Medical Center, Los Angeles, California, USA; through the National Hormone and Peptide Program). Brain sections were submitted to immunohistochemistry to detect pSTAT3 as a marker for leptin signaling.

Histology, hormone assays, and immunobistochemistry. Mice were deeply anesthetized with ketamine $(5 \mathrm{mg} / 100 \mathrm{~g})$ and xylazine $(1 \mathrm{mg} / 100 \mathrm{~g})$. Before perfusion or tissue collection, blood samples were collected directly from the heart. Hormone assays were performed by The University of Virginia Center for Research in Reproduction Ligand Assay and Analysis Core. Brain and reproductive organs were collected and post-fixed in buffered formalin. Brains were cut ( $25 \mu \mathrm{m}$ sections, 5 series) in a freezing microtome and stored at $-20^{\circ} \mathrm{C}$. Uteri, ovaries, and testes were processed for standard paraffin-embedded sectioning and $\mathrm{H} \& \mathrm{E}$ staining. Brain sections were processed for the detection of the reporter gene ( $\beta$-gal; Aves Lab), pSTAT3 (Cell Signaling Technology), Kisspeptin (Millipore), and GnRH (LHRH; Immunostar) immunoreactivity. Standard immunoperoxidase using DAB as chromogen as well as standard immunofluorescence using Alexa Fluor fluorophores-conjugated secondary antisera (Invitrogen) was used. 
In situ hybridization histochemistry. Brain sections were mounted onto SuperFrost plus slides (Fisher Scientific) and pretreated in $0.1 \mathrm{M}$ citric acid, $\mathrm{pH}$ 6.0, and microwave, as described (38). The riboprobes (GnRH, Kiss1, LepR, and vGluT2) were generated by in vitro transcription with ${ }^{35} \mathrm{~S}$-UTP. The ${ }^{35} \mathrm{~S}$-labeled probes were diluted $\left(10^{6} \mathrm{dpm} / \mathrm{ml}\right)$ in a hybridization solution that was applied to each slide, and sections were incubated overnight at $56^{\circ} \mathrm{C}$. Sections were submitted to stringency washes and dehydrated. Hybridization signal was detected following standard autoradiographic protocol. The specificity of GnRH, Kiss1, LepR, and vGluT2 probes was described before $(34,38,112)$.

Dual label in situ hybridization/immunohistochemistry. Hypothalamic sections containing the PMV of LepR-IRES-Cre LacZ mice $(n=3$ males and $n=3$ females) were submitted to in situ hybridization (vGluT2 riboprobes) followed by a standard immunoperoxidase for the detection of $\beta$-gal immunoreactivity (Aves Labs) using DAB as chromogen. The procedure is the same described in previous publications $(38,90)$. Slides were then processed for standard autoradiographic methods.

Quantification of bybridization signal and immunoreactivity. The hybridization signal (Kiss1 and GnRH) and the GnRH immunoreactivity were estimated by the analysis of integrated optical density (IOD) using ImageJ software (http://rsb.info.nih.gov/ij). The IOD values for Kiss 1 mRNA and GnRH immunoreactivity were calculated as the total IOD of a constant area subtracting the background. The IOD values for $G n R H$ mRNA/cell and Kiss 1 mRNA/cell were calculated as the total IOD of each GnRH neuron surrounding the vascular organ of the lamina terminalis and each Kiss1 neuron on one side of one representative section of the AVPV and Arc. We considered a neuron GnRH positive only if the cell had IOD values at least $3 \times$ higher than that of background. Because Kiss 1 expression is lower compared with GnRH, we considered a neuron Kiss 1 positive only if the cell had IOD values at least $2 \times$ higher than that of background. The number of GnRH neurons was obtained from 1 series of sections extending from the medial septal nucleus to the preoptic area. The number of Kiss1 neurons was obtained from 1 representative section of the AVPV and of the Arc.

Quantitative real-time PCR. Mice were decapitated, brains were removed, and the hypothalamus was divided in 2 blocks: 1 containing the preoptic area and medial septum and 1 containing the Arc. After RNA extraction using the TRIzol reagent (Invitrogen), $2 \mu \mathrm{g}$ of total RNA was incubated in DNase I (Roche Diagnostics) for 30 minutes at $37^{\circ} \mathrm{C}$. Subsequently, the cDNA was generated using random hexamers (Roche Diagnostics) and SuperScript II Reverse Transcriptase (Invitrogen) during incubation at $42^{\circ} \mathrm{C}$ for 50 minutes. We used the SYBR Green PCR master mix (Applied Biosystems) for quantitative real-time PCR analysis, and the assays were performed using an Applied Biosystems Prism $7900 \mathrm{HT}$ sequence detection system. The mRNA contents were normalized to $\beta$-actin content (forward: 5'-CATCGTGGGCCGCTCTA; reverse: 5 '-CACCCACATAGGAGTCCTTCTG), and the resulting values were expressed as fold change above control levels. The primers for $G n R H$ mRNA quantification were 5'-CCACTGGCCCCGTTCAC (forward) and 5'-GCTTCCTCTTCAATCAGACTTTCC (reverse). The primers for Kiss1 mRNA quantification were 5 -GGCAAAAGTGAAGCCTGGAT (forward) and 5'-GATTCCTTTTCCCAGGCATT (reverse).

Data analysis and production of photomicrographs. Sections of brain, uterus, ovary, and testis were analyzed in a Zeiss Axioplan or ApoTome microscope (Zeiss). Photomicrographs were produced by capturing images with a digital camera (Axiocam; Zeiss) mounted directly on the microscope. Imageediting software (Adobe Photoshop CS3) was used to combine photomicrographs into plates. Only the sharpness, contrast, and brightness were adjusted. Cytoarchitectonic details were added by using a camera lucida.

Statistics. Data are expressed as mean \pm SEM. Comparison between 2 groups was carried out using the unpaired 2-tailed Student's $t$ test. Oneway ANOVA followed by the pairwise Tukey test were used to compare 3 or more groups simultaneously. Statistical analysis was performed using GraphPad Prism software, and an $\alpha$ value of 0.05 was considered in all analyses. The net effect of the lesions of PMV neurons and adjacent sites (pSTAT3 and Kiss1 neurons in the Arc) on the copulatory plugs was evaluated by General Regression Models, using the software Statistica v.9 (Statsoft). Results were expressed as Pareto chart of $t$ values for coefficients.

\section{Acknowledgments}

We thank N. Dunning, M. Choi, S. Osborne-Lawrence, and S. Rovinsky for technical support. This work was supported by the NIH (R01HD061539 to C.F. Elias; R01MH61583 and RL1DK081185 to J.K. Elmquist; K08DK068069 and R01DA024680 to J.M. Zigman), Capes (to L.O. Margatho), and Fapesp (05/58997-4 to J. Donato Jr.; 05/59286-4 to C.F. Elias). C.F. Elias is a Distinguished Scholar in Medical Research (University of Texas Southwestern Medical Center [UTSW]). Histology of the reproductive organs was provided by the UTSW Molecular Pathology Core. Hormone assays were performed by The University of Virginia Center for Research in Reproduction Ligand Assay and Analysis Core, supported by the Eunice Shriver NICHD/NIH (SCCPIR) (U54-HD28934). We thank Aktar Ali and Laura Brule and the Mouse Metabolic Phenotyping Core at UTSW (supported by PL1 DK081182-01 and UL1RR024923).

Received for publication September 14, 2010, and accepted in revised form November 3, 2010.

Address correspondence to: Carol F. Elias, Division of Hypothalamic Research, Department of Internal Medicine, University of Texas Southwestern Medical Center, 5323 Harry Hines Blvd., Y6-220B, Dallas, Texas 75390-9077, USA. Phone: 214.648.0248; Fax: 214.648.5612. E-mail: carol.elias@utsouthwestern.edu.
1. Kennedy GC. Interactions between feeding behavior and hormones during growth. Ann N Y Acad Sci. 1969;157(2):1049-1061.

2. Frisch RE, McArthur JW. Menstrual cycles: fatness as a determinant of minimum weight for height necessary for their maintenance or onset. Science. 1974;185(4155):949-951.

3. Rittmaster RS, Deshwal N, Lehman L. The role of adrenal hyperandrogenism, insulin resistance, and obesity in the pathogenesis of polycystic ovarian syndrome. J Clin Endocrinol Metab. 1993; 76(5):1295-1300

4. Blüher S, Mantzoros CS. Leptin in reproduction. Curr Opin Endocrinol Diabetes Obes. 2007;14(6):458-464.

5. Biro FM, et al. Pubertal assessment method and baseline characteristics in a mixed longitudinal study of girls. Pediatrics. 2010;126(3):e583-e590.
6. Biro FM, Khoury P, Morrison JA. Influence of obesity on timing of puberty. Int J Androl. 2006; 29(1):272-277.

7. Freedman DS, Khan LK, Serdula MK, Dietz WH, Srinivasan SR, Berenson GS. The relation of menarcheal age to obesity in childhood and adulthood: the Bogalusa heart study. BMC Pediatr. 2003;3:3.

8. Herman-Giddens ME, et al. Secondary sexual characteristics and menses in young girls seen in office practice: A study from the pediatric research in office settings network. Pediatrics. 1997;99(4):505-512

9. Lakshman R, et al. Association between age at menarche and risk of diabetes in adults: results from the EPIC-Norfolk cohort study. Diabetologia. 2008;51(5):781-786.

10. Petridou E, Syrigou E, Toupadaki N, Zavitsanos X, Willett W, Trichopoulos D. Determinants of age at menarche as early life predictors of breast cancer risk. Int J Cancer. 1996;68(2):193-198.

11. Coleman DL. Obese and diabetes: two mutant genes causing diabetes-obesity syndromes in mice. Diabetologia. 1978;14(3):141-148.

12. Zhang Y, Proenca R, Maffei M, Barone M, Leopold L, Friedman JM. Positional cloning of the mouse obese gene and its human homologue. Nature. 1994; 372(6505):425-432.

13. Tartaglia LA, et al. Identification and expression cloning of a leptin receptor, OB-R. Cell. 1995; 83(7):1263-1271.

14. Barash IA, et al. Leptin is a metabolic signal to the reproductive system. Endocrinology. 1996; 137(7):3144-3147.

15. Chehab FF, Lim ME, Lu R. Correction of the sterility defect in homozygous obese female mice by 
treatment with the human recombinant leptin. Nat Genet. 1996;12(3):318-320.

16. Mounzih K, Lu R, Chehab FF. Leptin treatment rescues the sterility of genetically obese ob/ob males. Endocrinology. 1997;138(3):1190-1193.

17. Montague CT, et al. Congenital leptin deficiency is associated with severe early-onset obesity in humans. Nature. 1997;387(6636):903-908.

18. Farooqi IS, et al. Effects of recombinant leptin therapy in a child with congenital leptin deficiency. NEngl J Med. 1999;341(12):879-884.

19. Farooqi IS, et al. Beneficial effects of leptin on obesity, T cell hyporesponsiveness, and neuroendocrine/ metabolic dysfunction of human congenital leptin deficiency. J Clin Invest. 2002;110(8):1093-1103.

20. Zamorano PL, Mahesh VB, De Sevilla LM, Chorich LP, Bhat GK, Brann DW. Expression and localization of the leptin receptor in endocrine and neuroendocrine tissues of the rat. Neuroendocrinology. 1997; 65(3):223-228.

21. Kowalski TJ, Liu SM, Leibel RL, Chua SC Jr. Transgenic complementation of leptin-receptor deficiency. I. Rescue of the obesity/diabetes phenotype of LEPR-null mice expressing a LEPR-B transgene. Diabetes. 2001;50(2):425-435

22. Cohen P, et al. Selective deletion of leptin receptor in neurons leads to obesity. J Clin Invest. 2001; 108(8):1113-1121.

23. de Luca C, et al. Complete rescue of obesity, diabetes, and infertility in $\mathrm{db} / \mathrm{db}$ mice by neuronspecific LEPR-B transgenes. J Clin Invest. 2005; 115(12):3484-3493.

24. Quennell JH, et al. Leptin indirectly regulates gonadotropin-releasing hormone neuronal function. Endocrinology. 2009;150(6):2805-2812.

25. Finn PD, Cunningham MJ, Pau KY, Spies HG, Clifton DK, Steiner RA. The stimulatory effect of leptin on the neuroendocrine reproductive axis of the monkey. Endocrinology. 1998;139(11):4652-4662.

26. Baskin DG, et al. Leptin receptor long-form splicevariant protein expression in neuron cell bodies of the brain and co-localization with neuropeptide $\mathrm{Y}$ mRNA in the arcuate nucleus. J Histochem Cytochem. 1999;47(3):353-362.

27. Cheung CC, Clifton DK, Steiner RA. Proopiomelanocortin neurons are direct targets for leptin in the hypothalamus. Endocrinology. 1997; 138(10):4489-4492.

28. Smith JT, Acohido BV, Clifton DK, Steiner RA. KiSS1 neurones are direct targets for leptin in the ob/ob mouse. J Neuroendocrinol. 2006;18(4):298-303.

29. Huszar D, et al. Targeted disruption of the melanocortin-4 receptor results in obesity in mice. Cell. 1997;88(1):131-141.

30. Hohmann JG, et al. Differential role of melanocortins in mediating leptin's central effects on feeding and reproduction. Am J Physiol Regul Integr ComP Physiol. 2000;278(1):R50-R59.

31. Balthasar $\mathrm{N}$, et al. Leptin receptor signaling in POMC neurons is required for normal body weight homeostasis. Neuron. 2004;42(6):983-991.

32. van de Wall E, et al. Collective and individual functions of leptin receptor modulated neurons controlling metabolism and ingestion. Endocrinology. 2007; 149(4):1773-1785

33. Castellano JM, et al. Expression of hypothalamic KiSS-1 system and rescue of defective gonadotropic responses by kisspeptin in streptozotocin-induced diabetic male rats. Diabetes. 2006;55(9):2602-2610

34. Donato J Jr, et al. The ventral premammillary nucleus links fasting-induced changes in leptin levels and coordinated luteinizing hormone secretion. J Neurosci. 2009;29(16):5240-5250

35. McMinn JE, et al. An allelic series for the leptin receptor gene generated by CRE and FLP recombinase. Mamm Genome. 2004;15(9):677-685.

36. Cravo RM, et al. Characterization of Kiss1 neurons using transgenic mouse models [published online ahead of print November 18, 2010]. Neuroscience. doi:10.1016/j.neuroscience.2010.11.022.

37. Bates SH, et al. STAT3 signalling is required for leptin regulation of energy balance but not reproduction. Nature. 2003;421(6925):856-859.

38. Scott MM, et al. Leptin targets in the mouse brain. J Comp Neurol. 2009;514(5):518-532.

39. Smith JT, Cunningham MJ, Rissman EF, Clifton DK, Steiner RA. Regulation of Kiss1 gene expression in the brain of the female mouse. Endocrinology. 2005;146(9):3686-3692.

40. Smith JT, et al. Differential regulation of KiSS-1 mRNA expression by sex steroids in the brain of the male mouse. Endocrinology. 2005;146(7):2976-2984.

41. Bray GA. Obesity and reproduction. Hum Reprod. 1997;12 suppl 1:26-32.

42. Chan JL, Mantzoros CS. Leptin and the hypothalamic-pituitary regulation of the gonadotropingonadal axis. Pituitary. 2001;4(1-2):87-92.

43. Schwartz MW, Porte D Jr. Diabetes, obesity, and the brain. Science. 2005;307(5708):375-379.

44. Elmquist JK, Coppari R, Balthasar N, Ichinose M, Lowell BB. Identifying hypothalamic pathways controlling food intake, body weight, and glucose homeostasis. J Comp Neurol. 2005;493(1):63-71.

45. Woods SC, D'Alessio DA. Central control of body weight and appetite. J Clin Endocrinol Metab. 2008; 93(11 suppl 1):S37-S50.

46. Friedman JM. Leptin at 14 y of age: an ongoing story. Am J Clin Nutr. 2009;89(3):973S-979S.

47. Vasudevan K, Raber J, Sztein J. Fertility comparison between wild type and transgenic mice by in vitro fertilization. Transgenic Res. 2010;19(4):587-594.

48. Sisk CL, Nunez AA, Thebert MM. Differential effects of electrolytic and chemical hypothalamic lesions on LH pulses in rats. Am J Physiol. 1988; 255(5 pt 1):E583-E590

49. Chehab FF, Mounzih K, Lu R, Lim ME. Early onset of reproductive function in normal female mice treated with leptin. Science. 1997;275(5296):88-90.

50 . Coppari R, et al. The hypothalamic arcuate nucleus: a key site for mediating leptin's effects on glucose homeostasis and locomotor activity. Cell Metab. 2005; 1(1):63-72.

51. Morton GJ, et al. Arcuate nucleus-specific leptin receptor gene therapy attenuates the obesity phenotype of Koletsky $(\mathrm{fa}(\mathrm{k}) / \mathrm{fa}(\mathrm{k}))$ rats. Endocrinology. 2003; 144(5):2016-2024.

52. Nelson JF, Karelus K, Felicio LS, Johnson TE. Genetic influences on the timing of puberty in mice. Biol Reprod. 1990;42(4):649-655.

53. Johnson LM, Sidman RL. A reproductive endocrine profile in the diabetes $(\mathrm{db})$ mutant mouse. Biol Reprod. 1979;20(3):552-559.

54. Batt RAL, Everard DM, Gillies G, Wilkinson M, Wilson CA, Yeo TA. Investigation into the hypogonadism of the obese mouse (genotype ob/ob). J Reprod Fertil. 1982;64(2):363-371.

55. Quarmby VE, Korach KS. The influence of 17 \{beta\}estradiol on patterns of cell division in the uterus. Endocrinology. 1984;114(3):694-702.

56. Channing CP, Schaerf FW, Anderson LD, Tsafriri A. Ovarian follicular and luteal physiology. Int Rev Physiol. 1980;22:117-201.

57. Cameron JL, Nosbisch C. Suppression of pulsatile luteinizing hormone and testosterone secretion during short term food restriction in the adult male rhesus monkey (Macaca mulatta). Endocrinology. 1991;128(3):1532-1540.

58. Ahima RS, et al. Role of leptin in the neuroendocrine response to fasting. Nature. 1996; 382(6588):250-252.

59. Lane PW, Dickie MM. Fertile obese male mice. Relative sterility in obese males corrected by dietary restrictions. J Hered. 1954;45(2):56-58.

60. Bourguignon JP, Gerard A, Franchimont P. Direct activation of gonadotropin-releasing hormone secretion through different receptors to neuro- excitatory amino acids. Neuroendocrinology. 1989; 49(4):402-408.

61. Urbanski HF, Ojeda SR. A role for N-methyl-Daspartate (NMDA) receptors in the control of $\mathrm{LH}$ secretion and initiation of female puberty. Endocrinology. 1990;126(3):1774-1776.

62. Ojeda SR, et al. Minireview: the neuroendocrine regulation of puberty: Is the time ripe for a systems biology approach? Endocrinology. 2006;147(3):1166-1174.

63. Brann DW, Mahesh VB. Excitatory amino acids: function and significance in reproduction and neuroendocrine regulation. Front Neuroendocrinol. 1994;15(1):3-49.

64. DeFalco J, et al. Virus-assisted mapping of neural inputs to a feeding center in the hypothalamus. Science. 2001;291(5513):2608-2613.

65. Clarkson J, Herbison AE. Postnatal development of kisspeptin neurons in mouse hypothalamus; sexual dimorphism and projections to gonadotropin-releasing hormone neurons. Endocrinology. 2006;147(12):5817-5825

66. Polkowska J, Wójcik-Gladysz A, Wankowska M. The effect of intracerebroventricular infusions of leptin on the immunoreactivity of neuropeptide $\mathrm{Y}$ and gonadotrophin releasing hormone neurons in the hypothalamus of prepubertal sheep in conditions of short fasting. J Chem Neuroanat. 2006;32(1):65-73.

67. Considine RV, et al. Serum immunoreactiveleptin concentrations in normal-weight and obese humans. NEngl J Med. 1996;334(5):292-295.

68. Maffei M, et al. Leptin levels in human and rodent: measurement of plasma leptin and ob RNA in obese and weight-reduced subjects. Nat Med. 1995;1(11):1155-1161.

69. Ahima RS, Dushay J, Flier SN, Prabakaran D, Flier JS. Leptin accelerates the onset of puberty in normal female mice. J Clin Invest. 1997;99(3):391-395.

70. Yura S, et al. Accelerated puberty and late-onset hypothalamic hypogonadism in female transgenic skinny mice overexpressing leptin. J Clin Invest. 2000; 105(6):749-755.

71. de Roux N, Genin E, Carel JC, Matsuda F, Chaussain JL, Milgrom E. Hypogonadotropic hypogonadism due to loss of function of the KiSS1-derived peptide receptor GPR54. Proc Natl Acad Sci U S A. 2003; 100(19):10972-10976.

72. Seminara SB, et al. The GPR54 gene as a regulator of puberty. N Engl J Med. 2003;349(17):1614-1627.

73. Lapatto R, et al. Kiss1 / mice exhibit more variable hypogonadism than Gpr54 / mice. Endocrinology. 2007;148(10):4927-4936.

74. d'Anglemont de Tassigny X, et al. Hypogonadotropic hypogonadism in mice lacking a functional Kiss1 gene. Proc Natl Acad Sci U S A. 2007;104(25):10714-10719.

75. Navarro VM, et al. Advanced vaginal opening and precocious activation of the reproductive axis by KiSS-1 peptide, the endogenous ligand of GPR54. J Physiol. 2004;561(pt 2):379-386.

76. Navarro VM, et al. Developmental and hormonally regulated messenger ribonucleic acid expression of KiSS-1 and its putative receptor, GPR54, in rat hypothalamus and potent luteinizing hormonereleasing activity of KiSS-1 peptide. Endocrinology. 2004;145(10):4565-4574.

77. Han S-K, et al. Activation of gonadotropin-releasing hormone neurons by kisspeptin as a neuroendocrine switch for the onset of puberty. J Neurosci. 2005;25(49):11349-11356

78. Dhillo WS, et al. Kisspeptin-54 stimulates the hypothalamic-pituitary gonadal axis in human males. J Clin Endocrinol Metab. 2005;90(12):6609-6615.

79. Navarro VM, et al. Effects of KiSS-1 peptide, the natural ligand of GPR54, on follicle-stimulating hormone secretion in the rat. Endocrinology. 2005;146(4):1689-1697

80. Plant TM, Ramaswamy S, Dipietro MJ. Repetitive activation of hypothalamic $\mathrm{G}$ protein-coupled 
receptor 54 with intravenous pulses of kisspeptin in the juvenile monkey (Macaca mulatta) elicits a sustained train of gonadotropin-releasing hormone discharges. Endocrinology. 2006;147(2):1007-1013.

81. Shahab M, Mastronardi C, Seminara SB, Crowley WF, Ojeda SR, Plant TM. Increased hypothalamic GPR54 signaling: a potential mechanism for initiation of puberty in primates. Proc Natl Acad SciUS A. 2005;102(6):2129-2134.

82. Dungan HM, et al. The role of Kisspeptin GPR54 signaling in the tonic regulation and surge release of gonadotropin-releasing hormone/luteinizing hormone. J Neurosci. 2007;27(44):12088-12095

83. Simerly RB. Hormonal control of neuropeptide gene expression in sexually dimorphic olfactory pathways. Trends Neurosci. 1990;13(3):104-110.

84. Merchenthaler I, Lane MV, Numan S, Dellovade TL. Distribution of estrogen receptor alpha and beta in the mouse central nervous system: in vivo autoradiographic and immunocytochemical analyses. J Comp Neurol. 2004;473(2):270-291.

85. Coolen LM, Peters HJ, Veening JG. Fos immunoreactivity in the rat brain following consummatory elements of sexual behavior: a sex comparison. Brain Res. 1996;738(1):67-82.

86. Kollack-Walker S, Newman SW. Mating and agonistic behavior produce different patterns of Fos immunolabeling in the male Syrian hamster brain. Neuroscience. 1995;66(3):721-736

87. Yokosuka M, et al. Female-soiled bedding induced fos immunoreactivity in the ventral part of the premammillary nucleus (PMv) of the male mouse. Physiol Behav. 1999;68(1-2):257-261.

88. Cavalcante JC, Bittencourt JC, Elias CF. Female odors stimulate CART neurons in the ventral premammillary nucleus of male rats. Physiol Behav. 2006 88(1-2):160-166.

89. Leshan RL, Louis GW, Jo Y-H, Rhodes CJ, Munzberg $\mathrm{H}$, Myers MG Jr. Direct innervation of GnRH neurons by metabolic- and sexual odorant-sensing leptin receptor neurons in the hypothalamic ventral premammillary nucleus. J Neurosci. 2009 29(10):3138-3147.

90. Donato J Jr, Cavalcante JC, Silva RJ, Teixeira AS, Bittencourt JC, Elias CF. Male and female odors induce Fos expression in chemically defined neuronal population. Physiol Behav. 2010;99(1):67-77.

91. Beltramino C, Taleisnik S. Ventral premammil- lary nuclei mediate pheromonal-induced LH release stimuli in the rat. Neuroendocrinology. 1985; 41(2):119-124

92. Mounzih K, Qiu J, Ewart-Toland A, Chehab FF. Leptin is not necessary for gestation and parturition but regulates maternal nutrition via a leptin resistance state. Endocrinology. 1998;139(12):5259-5262.

93. Nagatani S, Guthikonda P, Thompson RC, Tsukamura H, Maeda KI, Foster DL. Evidence for GnRH regulation by leptin: leptin administration prevents reduced pulsatile LH secretion during fasting. Neuroendocrinology. 1998;67(6):370-376.

94. Gonzalez LC, Pinilla L, Tena-Sempere M, Aguilar E. Leptin(116-130) stimulates prolactin and luteinizing hormone secretion in fasted adult male rats. Neuroendocrinology. 1999;70(3):213-220.

95. Chan JL, Mantzoros CS. Role of leptin in energydeprivation states: normal human physiology and clinical implications for hypothalamic amenorrhoea and anorexia nervosa. Lancet. 2005;366(9479):74-85.

96. Welt CK, et al. Recombinant human leptin in women with hypothalamic amenorrhea. $N$ Engl J Med. 2004:351(10):987-997.

97. Ichikawa S, Morioka H, Sawada T. Acute effect of gonadotrophins on the secretion of progestins by the rat ovary. Endocrinology. 1972;90(5):1356-1362.

98. Sodersten P, Eneroth P. Serum levels of oestradiol-17\{beta\} and progesterone in relation to sexual receptivity in intact and ovariectomized rats. J Endocrinol. 1981;89(1):45-54.

99. Adler NT, Resko JA, Goy RW. The effect of copulatory behavior on hormonal change in the female rat prior to implantation. Physiol Behav. 1970;5(9):1003-1007.

100. Moley KH. Hyperglycemia and apoptosis: mechanisms for congenital malformations and pregnancy loss in diabetic women. Trends Endocrinol Metab. 2001;12(2):78-82

101. Metwally M, Ong KJ, Ledger WL, Li TC. Does high body mass index increase the risk of miscarriage after spontaneous and assisted conception? A meta-analysis of the evidence. Fertil Steril. 2008;90(3):714-726

102.Lashen H, Fear K, Sturdee DW. Obesity is associated with increased risk of first trimester and recurrent miscarriage: matched case-control study. Hum Reprod. 2004;19(7):1644-1646.

103.Hummel KP, Dickie MM, Coleman DL. Diabetes, a new mutation in the mouse. Science. 1966;
153(740):1127-1128

104. Rondini TA, Baddini SP, Sousa LF, Bittencourt JC, Elias CF. Hypothalamic cocaine- and amphetamine-regulated transcript neurons project to areas expressing gonadotropin releasing hormone immunoreactivity and to the anteroventral periventricular nucleus in male and female rats. Neuroscience. 2004;125(3):735-748.

105.Boehm U, Zou Z, Buck LB. Feedback loops link odor and pheromone signaling with reproduction. Cell. 2005;123(4):683-695

106.d'Anglemont de Tassigny X, Ackroyd KJ, Chatzidaki EE, Colledge WH. Kisspeptin signaling is required for peripheral but not central stimulation of gonadotropin-releasing hormone neurons by NMDA. J Neurosci. 2010;30(25):8581-8590.

107. Wójcik-Gladysz A, Wankowska M, Misztal T, Romanowicz K, Polkowska J. Effect of intracerebroventricular infusion of leptin on the secretory activity of the $\mathrm{GnRH} / \mathrm{LH}$ axis in fasted prepubertal lambs. Anim Reprod Sci. 2009;114(4):370-383.

108.Yu WH, Walczewska A, Karanth S, McCann SM. Nitric oxide mediates leptin-induced luteinizing hormone-releasing hormone (LHRH) and LHRH and leptin-induced LH release from the pituitary gland. Endocrinology. 1997;138(11):5055-5058.

109. Parent AS, Lebrethon MC, Gerard A, Vandersmissen E, Bourguignon JP. Leptin effects on pulsatile gonadotropin releasing hormone secretion from the adult rat hypothalamus and interaction with cocaine and amphetamine regulated transcript peptide and neuropeptide Y. Regul Pept. 2000;92(1-3):17-24.

110.Lebrethon MC, Vandersmissen E, Gerard A, Parent AS, Bourguignon JP. Cocaine and amphetamineregulated-transcript peptide mediation of leptin stimulatory effect on the rat gonadotropin-releasing hormone pulse generator in vitro. J Neuroendocrinol. 2000;12(5):383-385.

111.Lebrethon MC, Vandersmissen E, Gerard A, Parent AS, Junien JL, Bourguignon JP. In vitro stimulation of the prepubertal rat gonadotropin-releasing hormone pulse generator by leptin and neuropeptide Y through distinct mechanisms. Endocrinology. 2000;141(4):1464-1469.

112.Tong Q, et al. Synaptic glutamate release by ventromedial hypothalamic neurons is part of the neurocircuitry that prevents hypoglycemia. Cell Metab. 2007;5(5):383-393 